\title{
INERTIAL REPRODUCTION: IS THE TWO-CHILD PSYCHOLOGY THE RULE IN COSTA RICA?
}

\author{
Laura C. Blanco ${ }^{1}$
}

\begin{abstract}
This paper uses data from National Surveys on Sexual and Reproductive Health to test whether variables related to identity, sexuality and contraceptive knowledge are associated with the preference and demand for children in Costa Rica. Both the preferred and actual number of children are estimated with a double hurdle model. The findings indicate that preferences for children seem to be quite fixed around two children and are mainly associated with religious beliefs and the person's gender, but they are not found to be associated with human capital. In contrast, the probability of having a child and the number of children are related to investment in human capital and sex education. Hence, human capital might be relevant in bringing a child into the world, but not in the initial preference.
\end{abstract}

KEY WORDS: REPRODUCTION, PREFERENCE FOR CHILDREN, DEMAND FOR CHILDREN, GENDER, CONTRACEPTIVE KNOWLEDGE, COSTA RICA.

CLASIFICACIÓN JEL: D19, D91, J13.

\section{RESUMEN}

Se utilizan las Encuestas Nacionales de Salud Sexual y Reproductiva para someter a prueba si existe una relación entre la identidad, la sexualidad y el conocimiento de anticonceptivos con las preferencias y la demanda reproductiva en Costa Rica. Tanto el tamaño preferido de descendencia como el tamaño de descendencia efectivo se estima utilizando un modelo de truncamiento doble. Los resultados muestran que las preferencias reproductivas son bastante estáticas alrededor de dos descendientes y se encuentran principalmente asociadas a creencias religiosas y el género de la persona, pero no con el capital humano. En contraste, la probabilidad de tener una hija o un hijo y el tamaño de la descendencia se relacionan con la inversión en capital humano y la educación sexual. Por tanto, el capital humano es relevante para la decisión de traer a una persona al mundo, pero no para la preferencia inicial.

PALABRAS CLAVE: REPRODUCCIÓN, PREFERENCIAS REPRODUCTIVAS, DEMANDA REPRODUCTIVA, GÉNERO, CONOCIMIENTO ANTICONCEPTIVO, COSTA RICA.

JEL CLASIFICATION: D19, D91, J13.

1 Universidad de Costa Rica, Escuela de Economía; Código postal 11501-2060; San José, Costa Rica; lauracristina.blanco@ucr.ac.cr 


\section{INTRODUCTION}

The economic literature consistently provides evidence that children have a negative, or at least a non-positive effect, on life satisfaction (Di Tella, MacCulloch \& Oswald 2003; Clark \& Oswald, 2002), happiness (Glenn \& McLanahan, 1981; Alesina, Di Tella \& MacCulloch, 2004; Margolis \& Myrskylä, 2011), marital satisfaction (Twenge, Campbell \& Foster, 2003), spousal love (Grossbard \& Mukhopadhyay, 2012) and financial and leisure satisfaction (van Praag, Frijters \& Ferrer-iCarbonell, 2003). The literature also suggests that the effect of children on well-being varies across groups: children contribute negatively to well-being when people face harsh circumstances (Dolan, Peasgood, \& White, 2008) and to happiness when people are poor (Alesina et al., 2004) or have lesser financial resources or live in liberal -rather than welfare- states (Margolis \& Myrskylä, 2011), while women, high socioeconomic groups and younger birth cohorts report higher marital dissatisfaction after the birth of a child (Twenge et al., 2003). Women also report a higher loss of spousal love than men (Grossbard \& Mukhopadhyay, 2012). Similarly, there is some evidence of decreasing returns on having children: the gains in happiness turn negative or non-significant after the second child (Kohler, Behrman \& Skytthe, 2005; Myrskylä \& Margolis, 2014) and well-being decreases the most for women with three or more children (Clark \& Oswald, 2002).

Even in the long-run, there is mixed evidence on the effect of reproduction on happiness: while Glenn and McLanahan (1981) find a persistent negative effect; Margolis and Myrskylä (2011) argue that the impact of reproduction on happiness varies along the life-cycle: happiness decreases with the number of children during childbearing, flattens and later increases as children grow older, especially for those parents who become sick during their elder years because their children provide them with care and serve as an insurance mechanism. In a more recent paper, Myrskylä and Margolis (2014) find that happiness initially increases prior and during the first two years of the birth, but, on average, it later returns to its pre-birth setpoint. However, these effects vary across group: reproduction exhibits long-term negative effects for young parents and positive long-term effects for better educated and older ones.

Given the overwhelming evidence that, on average, children are, at best, not detrimental to well-being, it is worth asking why do people reproduce at all. The question seems to be more relevant for women, since they are the ones most negatively affected by reproductive decisions. This paper uses regression analysis to estimate both the preference for children and the observed demand for children for women and men in Costa Rica using the National Surveys on Sexual and Reproductive Health. This allows the identification of the correlates associated with reproductive decisions in a developing country. Previous research has used the data collected in this survey during 2010 to analyze demographic trends and fertility rates (Robles \& González, 2012a), but to my knowledge the data collected in the 2015 survey has not yet been analyzed. The research also differs from the previous one in that it does not solely focus on the effective demand for children. Instead, it also aims at understanding whether the factors associated with child preferences are the same as those related to the observed demand for children. In order to do this, a double-hurdle model is specified to estimate both the preference and the observed demand for children. Aside from the usual human capital variables, this paper explores whether variables proxying identity, sexuality and contraceptive knowledge are associated with both the preference for and the observed demand for children.

Indeed, the findings show that the stated preferences and the demand for children respond to different variables. In general, preferences for children seem to be quite fixed around a constant value and are mainly associated with religious beliefs but they are not found to be associated with 
human capital. In contrast, the observed demand for children is related to an array of social and economic variables. In particular, it is associated with the investment in human capital and sex education. The latter suggest that in an abstract or ideal world, people might carry an innate or unconscious idea about having two offspring, but when this idea is confronted with reality, their economic and educational possibilities as well as their experience gained through age and their identity construction produce an outcome that differs from their imaginariness.

\section{BACKGROUND}

Despite the negative impact of children on well-being, when asked, most people claim to want to have not one, but two children (Carey \& Lopreato, 1995). This is known as the two-child psychology hypothesis, proposed by Lopreato and Yu (1988) and inspired in the Malthusian and Darwinian theories. According to this hypothesis, there is an innate behavioral predisposition according to which women aim at having two surviving offspring. Evolutionary gains are weighed against the costs of reproduction (such as the risks of maternal and child mortality, comfort and happiness) in order to optimize the available resources and continuation of the species. Therefore, as societies develop and infant survival rates approach unity, two-child families become the norm, due to natural selection: that is, if an individual plans to have two surviving children and the probability of survival is high, then she or he will plan to have on average, a little over 2 children. Costa Rica might be an example of this ${ }^{2}$. According to the Costa Rican National Surveys on Sexual and Reproductive Health (Centro Centroamericano de Población, 2010, 2015), almost half the population over 15 years of age reports wanting to have two offspring, although it seems they end up having less children than the ones initially desired: Costa Rica's fertility rate reached 1.83 children per women in 2010 (Robles \& González, 2012a, p.19), which is part of a decreasing trend since the nineteen sixties (Rosero-Bixby \& Oberle, 1989; Rosero-Bixby \& Casterline, 1995). Aside from this evolutionary explanation, Lopreato and $\mathrm{Yu}$ (1988) also argue that participation in the labor market and literacy are the main explanatory factors of fertility, hinting that fertility is not only a response of evolutionary factors, but social ones as well.

In contrast, Goldstein, Lutz and Testa (2003) argue that, while the ideal number of children has been stable above the replacement rate in Europe (i.e., above 2 children), this might be beginning to change, since it has decreased in time and it is below the replacement rate in Austria and Germany. Further, women also expect to have less children than their ideal number. The reason for this decline is not biological, as in Lopreato and Yu (1988), but rather cultural: as younger cohorts are born and raised in small families and a context of low-fertility norms, their preferences are shaped to favor this type of families, which results in a time trend of declining ideal family size.

Also drawn from the Malthusian and Darwinian theories is Becker's (1991) quantity-quality model. He argued that his was a more general model because it included the possibility of cultural selection and introduced the cost-benefit analysis at an individual level (rather than just at the genetic one). Becker's (1960; 1991) and Schultz' (1974; 1997) models have become the standard in measuring

2 In Costa Rica, the neonatal mortality rate is 6.2 per 1000 live births, the infant mortality rate is 8.2 per 1000 live births and the mortality rate for children under 5 is 9.7 per 1000 children (World, Bank 2017), so parents presumably make their decisions with a low expectation of their children dying at an early age. 
the demand for children in the study of household economics ${ }^{3}$. According to these, a person's utility includes not just the quantity of children wanted, but their quality as well, which is achieved through human capital investment. As a result, the quantity and quality of children are substitute goods. That is, those people whose preferences are inclined towards quality end up having less children because this allows them to invest more human capital in them.

In its reduced form, these models follow Mincer (1974), so that the quantity of children is a function of education, household income, child mortality, wealth, agricultural work and the region where one lives. Education and income measure the shadow price of time: as people become more educated their opportunity cost of having children (i.e., their labor market earnings) increases, which leads to a reduction in the number of children. At the same time, the increase of educational attainment is associated with an older age of first birth and the acquisition of certain values and attitudes, including a higher attachment to the labor market that might be negatively related to fertility (Neels, Murphy, Bhrolcháin \& Beaujouan, 2017). The impact of income on the demand for children might also differ due to the household members' specialization, particularly so for women: for those specialized in the labor market, the opportunity cost of a child is higher and, therefore, she would demand less children than a woman who specializes in household production.

Non-labor income is usually introduced as a proxy for wealth. If children are normal goods, wealthier families would demand more children due to an income effect. However, both income and wealth might also reflect other noneconomic variables. For example, the level of education and norms might influence the demand for children through income (Bagozzi \& Van Loo, 1978). These also serve as a signal of family status, which is ultimately exhibited through a proportional higher consumption of status goods. Because this type of goods is more expensive, the opportunity cost of an additional child is higher for high-status than that for low-status people. Therefore, the former would demand less children due to a difference in preferences (Bagozzi \& Van Loo, 1978).

Living in a rural area and working in agriculture are indicative of the cost of having children and tenure of financial wealth, respectively. It used to be that the living costs in rural areas were lower than in urban areas and children were considered an asset because they could work and inherit the land afterwards, so families in rural areas had more children. This might no longer be true because urban areas offer access to more and cheaper services than rural areas and because children became consumption goods rather than assets, which makes unclear the expected sign of these variables.

It is also customary to control for religion, since religious people tend to have more children (Schultz, 1997) and are more likely to have unplanned pregnancies (Grossbard \& Mukhopadhyay, 2012). Further, religion institutionalizes gender roles and reinforces values associated with it, which might be reflected in differences between fertility rates among religious groups (McQuillan, 2004). Religious people might also be more exposed to pro-natalist pressures and, consequently, exhibit higher fertility rates (Bagozzi \& Van Loo, 1978).

3 Becker's (1960) initial model is not exempt of critiques. For example, Turchi (1975) criticizes that Becker's model is static and unitary instead of dynamic, lacks a measurable notion of child quality, does not incorporate normative pressures into the household utility function that is being maximized (such as ambition or ability), people cannot really estimate the true discounted value of raising a child versus its benefits, and ignores the cost and access to contraception as well as the social and psychic context of childrearing. Llovet (1989) and Bagozzi \& Van Loo (1978) make similar critiques regarding the homogeneity of preferences, the failure to model tastes and the decision process within the household. Further, McDonald (2002) argue that the gains from reproduction are mainly psychological and difficult to calculate, which poses estimation difficulties. However, Becker (1991) later improved his model and addressed the most severe of these critiques, such as the one differentiating between the income and wealth effect, as well as the differences in the income effect of the person specializing in the household production or the labor market. This is still the basic reference model in household economics for understanding the demand for children and will be used as such throughout this paper. 
Finally, child mortality enters the model as a measure of parental expectations on the probability of their offspring's survival rate, so as child mortality drops, the demand for children decreases, which is consistent with Lopreato and Yu's (1988) hypothesis mentioned earlier and the demographic transition theory (Preston, 1978). That is, experiencing child mortality (Preston, 1978) or induced abortion, perinatal death and natural abortion increases the odds of subsequent pregnancy (Ganaba, et al., 2010). This could generate either a replacement or a hoarding behavior, i.e., families either have additional children to substitute the ones who died or generate a precautionary demand that serves as insurance when survival rates are uncertain (Preston, 1978; Bousmah, 2014). Child survival is consistently associated with birth spacing, which in turn is associated with the lactational amenorrhea method, a natural contraceptive observed during the breastfeeding period and access to health care (Preston, 1978; Potter, 1988). The latter is particularly important, because health care access allows women to access contraception, which reduces the risk of neonatal, infant, and child mortality (Yeakey et. al., 2009; Mekonnen, \& Worku, 2011), as well as maternal death (Prata, 2009; Malarcher et al., 2011, Ahmed, Li, Liu, \& Tsui, 2012), especially for teenagers (Kennedy, Gray, Azzopardi, \& Creati, 2011). For Costa Rica, however, child mortality has not been found to be significant in explaining fertility, after controlling for socio-economic conditions (Rosero-Bixby, 1998), although women are more likely to use contraception in low-mortality counties, suggesting that a low-mortality context might facilitate the fertility transition, although lower child mortality is not a prerequisite for a lower fertility equilibrium (Rosero-Bixby, 1998).

Other approaches emphasize the role of culture and institutions in explaining fertility. For example, the norms corresponding to a person's status -proxied by religion, age or residence-, the standards of childrearing and family size also determine the perceived price of children and, therefore, help shape preferences for children, for goods and for the expected age of marriage and first birth (Turchi, 1975; Bagozzi \& Van Loo, 1978). Fertility and contraception are not determined solely by economic variables such as income, but also by an individual's social status, her or his economic environment and by society's sex-role norms, particularly those governing gender attitudes and behaviors within marriage (Bagozzi \& Van Loo, 1978). Parents from higher social status and education are more likely to breed children with egalitarian values and, in turn, their children are more likely to marry later in life and have fewer births. The reason for it is that egalitarian couples are more career-oriented, more likely to use contraception, be anti-natalist and aspire to a higher lifestyle. In contrast, men from lower classes equate their idea of womanhood with motherhood and tend to have more children (Bagozzi \& Van Loo, 1978). Institutions not only influence fertility decisions through the reinforcement of values, but also through policies. People are less likely to reproduce if the labor market lacks family-friendly policies such as parental leave, childcare subsidies, antidiscrimination legislation and gender equity, or if it has long working hours. Because people tend to be risk averse, as the market becomes more liberal, people would seek to invest in economic security rather than reproduce and face the uncertainty of caring for dependents (McDonald, 2002).

The empirical findings show that female income has the strongest negative effect on fertility, while wealth and non-labor income have a positive effect (Becker, 1992; Schultz, 1997). Male income and education are not significant in explaining fertility (De Tray, 1974; Schultz, 1997), although self-employed men do demand more descendance, particularly, a male descendance to ensure the continuity of their business (Broussar, 2013). The evidence also finds that more educated women have less children and spend more time with them (Becker, 1992; De Tray, 1974; Schultz, 1997; Frenette, 2011), supporting the quantity-quality theory. In contrast, more recent data suggests that female reproductive decisions are mainly associated with childcare costs rather than with female education (Mörk, Sjögren \& Svaleryd, 2013). Thus, some authors argue that the quantity-quality model must be verified when people acquire childcare services (Lundholm \& Olhsson, 2002). This could lead to cases where more educated women demand more children because they can afford the high-quality childcare (Hazan \& Zoabi, 2015). Similarly, Kalwij (2000) argues that education does not determine 
the number of children as much as female employment, and that the evidence does support the quantity-quality model.

In Costa Rica, reproductive decisions have been found to be correlated with a person's schooling level: specifically, finishing high school has been associated with a lower fertility rate and a higher age of first birth (Robles \& González, 2012a). The fertility rate has also been higher for women in urban areas, where resources are more available, and the number of women reporting not wanting to reproduce has increased over time, as their opportunity cost increased too (Robles \& González, 2012a). All these findings are consistent with Becker's quantity-quality model. The most recent study on fertility in Costa Rica is that of Robles and González (2012a). They estimate fertility rates since 1950 and identify four periods: from 1950 to 1961 fertility rates increased to around 8 children per women. From 1962 to 1976, the introduction of contraception reduced the fertility rate to 3.63 children per women. The third period was one of stagnation and goes from 1977 to 1989. Finally, the fourth period extends from 1990 to the present and is marked by a decreasing trend in fertility. The replacement fertility rate was reached in 2002 and has stayed below 2 children per women since 2005 . The authors argue that this decrease in fertility is a response to institutional changes that make it more expensive for men to reproduce: since men can now be forced to pay child support, this led to a change in preferences. They also find that lower fertility rates are correlated with having a high school diploma and living in rural areas. This paper complements theirs by using regression analysis to identify the correlates of the preferences and demand for children in Costa Rica.

There seems to be, however, evidence that institutional, identity and gender factors might also be explaining part of these reproductive decisions in Costa Rica: women report, on average, a desire for less children than men, $47 \%$ of women in reproductive age did not want their last pregnancy (Quirós Rojas, 2012), contraceptive prevalence is just 81\% (Robles \& González, 2012b) and women do not enjoy whole reproductive rights, since the Costa Rican State is constitutionally Catholic. Therefore, data suggests that reproductive preferences might differ between genders due to cultural factors not included in the quantity-quality model and that the quantity of children demanded might not be optimal, inasmuch observed demand for children (i.e., the quantity of children effectively had, given their shadow price) does not match the stated preferences. Could it be that the reported preferences and the demand for children are driven by different factors? It might be possible that while reproductive preferences are driven at a more unconscious, evolutionary level, the actual decision of reproducing is negotiated in a more complex situation that leads to an outcome different from the one preferred. For example, a woman might end up with more children than she would prefer if her partner had more bargaining power in the household, if she did not have access to full reproductive rights or if she believed she was in fault of religious or gender norms she feels obliged to comply to.

Given that the construction of gender in a society influences a person's identity and their own life projects (de Beauvoir, 1999; Friedan, 2010), reproductive preferences might vary between women and men due to their beliefs and experiences associated with gender and sexuality. If people shape their identity around gender scripts, they will reproduce behavioral patterns to conform and validate their self-image around that idea of what it means to be a woman or a man. At the same time, people with beliefs that contest those gender norms will be expected to deviate from those gender scripts. The same can be said about education, especially that related to sexuality and birth control. Since the introduction of Enovid in 1960 (1962 in Costa Rica), contraceptive methods have been essential in allowing women take hold of their own lives: faced with the possibility of controlling the quantity and timing of pregnancies, women have increased their labor force participation, their investment in human capital, their expectations on the returns to tertiary education and their age at first marriage (Bailey, 2006; Goldin \& Katz, 2002), as well as their economic outcomes (Klepinger, Lundberg \& Plotnick, 1999). Because contraception separates the sexual function from the reproductive one, women are now able to plan their life projects, not as beings-for-others, subjected to biology, but as 
agent and autonomous beings. This explains the improved economic outcomes observed after the introduction of the pill. It comes as no surprise, then, that the decline in fertility is associated with the provision of family planning methods, particularly, those that are subsidized and are therefore, more widely accessible to women (Schultz, 1997). In contrast, without access to information on and availability of contraception people cannot control and time their reproductive decisions. This is problematic in a country like Costa Rica, where sexual education was unavailable in the school system prior to 2013 and teenagers do not have access to contraception without parental permission. In fact, $15 \%$ of registered births in Costa Rica are from teenage mothers and 42\%, from mothers under 25 years of age (Instituto Nacional de Estadística y Censos, 2017). For all of the above, identity, gender and contraceptive knowledge are considered as variables of interest in understanding reproductive preferences throughout this paper.

\section{DATA AND METHODS}

\section{Dataset}

This paper uses data from the National Survey on Sexual and Reproductive Health for the years 2010 and 2015. Access to the latest survey was provided by the Centro Centroamericano de Población (2010; 2015), the institution in charge of collecting the data. This dataset has several advantages relative to other national datasets such as the household survey or census data. First, it provides information on the number of children the person considered optimal. It asks for the total number of children wanted in life to those people with no children and the total number of children wanted in life before having any children for those who already have a child. No other survey asks this question in Costa Rica. Secondly, the survey includes information both on women and men, as well as information on values relative to gender ${ }^{4}$ and sexuality. Thirdly, survey respondents on reproductive health are usually married women, ages 15 to 49 (i.e., in reproductive age), such as, for example, participants of the Demographic and Health Surveys (The DHS Program, 2018). The Costa Rican survey has the advantage that it collects data on both women and men, ages 15 and over. Therefore, it provides access to information from non-married women as well as men and people who have concluded their reproductive period, which allows for a broader analysis. The same can be said of the availability of information on gender, identity and contraceptive knowledge.

In 2010, the National Survey on Sexual and Reproductive Health collected information on sexual practices, sexual history, contraceptive knowledge and use, fertility, reproductive preferences, knowledge and history on sexual health, and beliefs on reproductive rights, sexual practices and sexuality of Costa Rican residents ages 15 and over. The survey also asked respondents for some basic economic variables at an individual level, but not at a household level. It surveyed 1596 women and 1601 men, for a total of 3197 observations. In 2015, the survey was collected again but it excluded some questions, especially those regarding sexual practices and sexual identity. Instead, it contained a module on smoking and extended the questions on health beyond sexual health. This time, the survey included 1677 female respondents and 1539 men, that is 3216 observations in total. Another

4 Sex is biological and refers to having a female or male body. Gender, on the other hand, is a social construct about what it means to become and to be a woman or a man. This paper focuses on how gender -not sex- is associated with the taste and demand for children, i.e. the binary construct that society imposes on women and men regarding their roles, values and place in society. Therefore, an effort is made to identify variables that might serve as instruments proxying for this. In this regard, it is helpful that the dataset used asks people to identify as woman or men, not whether they have a male or female body. 
main difference between both surveys is that the 2015 dataset does not include a variable to account for population weights. A query was made, but weights could not be identified. Therefore, the results presented in this paper are unweighted and should be taken as representative of the sample. Given the survey methodology, there is no reason to believe that this generates any selection bias. Finally, observations with missing values, incoherent answers and outliers were dropped, which leaves a balanced sample of 5644 observations ( $88 \%$ of the initial sample). Of these, $50.97 \%$ belong to the 2010 survey and $49.03 \%$, to the 2015 dataset. There is no evidence of attrition in the balanced sample: the equality of proportion z-test for categorical variables and the equality of means t-test for continuous variables suggest that all the values obtained from the balanced sample are not significantly different from those in the whole dataset, none of the variables had more than $5 \%$ missing values and there were no patterns that could suggest attrition ${ }^{5}$.

\section{Variable descriptions}

Figure 1 depicts the distribution of the stated preferences for children by women and men in Costa Rica during 2010 and 2015. The most obvious remark about this distribution is how disproportionately people prefer having two children: by 2015, 42.8\% of women and 44\% of men stated their preference for two offspring. This figure, however, is slightly lower -but statistically differentthan the figure reported in 2010: by then $44.2 \%$ of women and $47.8 \%$ of men expressed a desire for two offspring. Similarly, almost two thirds of women and men declared wanting 2 or 3 children, albeit this percentage has slightly declined.

FIGURE 1

DISTRIBUTION OF THE PREFERENCES FOR CHILDREN IN 2010 AND 2015, BY GENDER

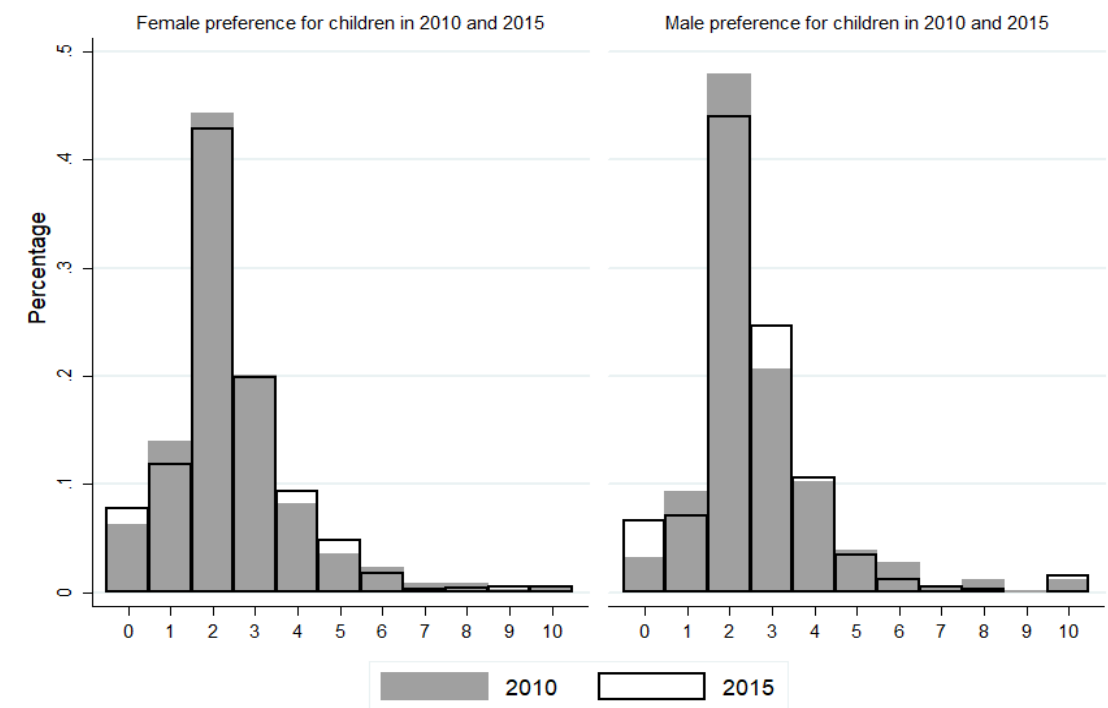

Source: Author's estimates, using data from Centro Centroamericano de Población (2010, 2015). 
The second characteristic of these distributions is a clear increase of the percentage of people who do not want to become parents: in just five years, the percentage of women in this category increased by almost 2 percentage points (p.p.) and the percentage of men, by 3.5 p.p. This increase is accompanied by a reduction of the people who want one child of about 2 p.p. for both women and men and a smaller increase of women who want numerous families, with 4 or more children. As a result, the average of the preferred number of children has remained quite stable at 2.5 children, which is slightly higher than the estimated replacement fertility rate for Costa Rica of 2.1 children per women (Robles \& González, 2012a). This is consistent with Lopreato and $\mathrm{Yu}$ (1988). But although the average preference for children is stable at around 2.5 children, it is still interesting that the changes in preferences are moving towards the ends of the distributions and not the middle: people who before might have thought of having one child, are preferring to remain childless, while women who might have wanted 2 or 3 children are now favoring more numerous families. Evidently, because there are only two observations available, this is not enough information to mark a trend. Similarly, the changes in the distribution, although statistically significant, are small, but this might be something to monitor in the future.

The third characteristic observed in Figure 1 is that men have a stronger preference for children than women. In 2015, one out of five women wanted one child or less, but only $13.7 \%$ of men stated such preferences. Men were 1.13 times more likely than women to claim to want three or more children and 2.7 times more likely to claim to want ten children. As a result, men wanted, on average, 2.57 children, while women preferred 2.44. This gap, however, is narrower than the one observed in 2010, when men wanted, on average, 2.65, 0.24 more children than women.

Ironically, on average, women end up having not only more children than they would like to, but also more children than the men (see Figure 2). In both years, sampled women reported having, on average, about 2 children, while men reported 1.5 children (with no statistical difference observed between 2010 and 2015). A comparison of the distributions across years shows a decrease of 7.8 p.p. in the percentage of childless women and of $4.4 \mathrm{pp}$. in men. The percentage of women and men with six or more children has also decreased slightly over 1 p.p., while the share of women and men with one or two children has increased around 6 p.p. Therefore, the distributions observed in 2015 are flatter than the ones in 2010 and are more compressed around the two children family structure.

FIGURE 2

\section{DISTRIBUTION OF THE NUMBER OF CHILDREN IN 2010 AND 2015, BY GENDER}

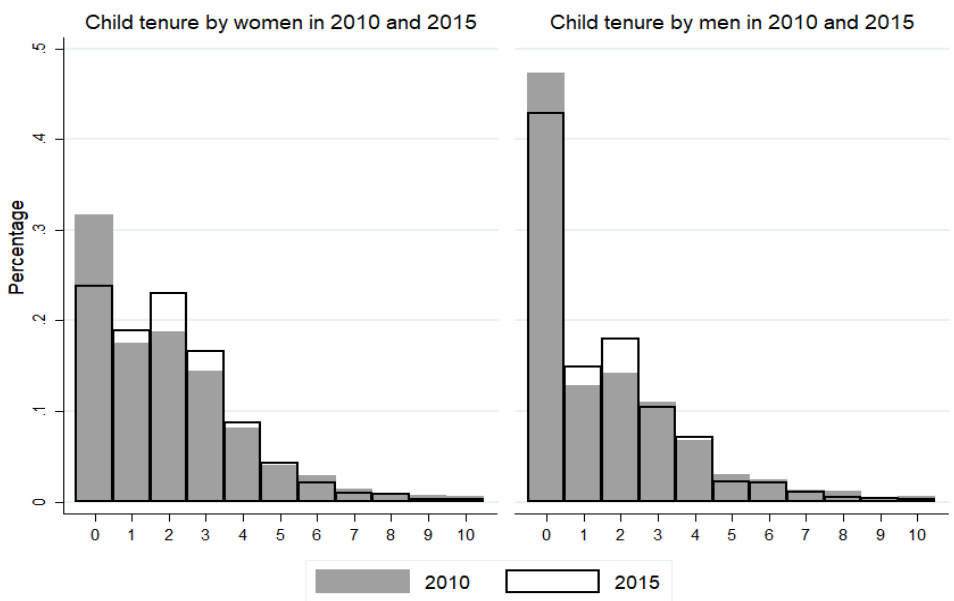

Source: Author's estimates, using data from Centro Centroamericano de Población (2010, 2015). 
The previous charts confirm that women are the biggest losers when bargaining their reproductive decisions. Figure 3 plots the average desired number of children and the average tenure of children by gender and age group in 2010 and 2015. Younger female cohorts have not met their ideal fertility, since they are still early in their reproductive cycle. In contrast, women between 35 to 39 years of age seem to have reached their ideal family size. Older female cohorts, however, have, on average, more children than they would like. A similar pattern is observed for men: men over 55 in 2010, and over 45 in 2015 report having more children than desired. This could be due to barriers to contraception or poor planning on their part. But for women, this situation seems to be more burdensome, since it affects more cohorts. Also, women below fifty report having, on average, more children than their male counterparts, which might be explained by the traditional pattern of male abandonment. Men over 55 years of age, on the other hand, report more children than the women in the same age cohort. A possible explanation is that they might be starting new families with younger women, but this hypothesis cannot be verified with the current surveys. Figure 3 also depicts a more abrupt change in male preferences for children: while in 2010 men of all age groups wanted more children than the women of their same age and this gap widened for people in older age groups, by 2015 this was no longer the case, because the preferences had become flatter around 2.5 children for both genders, but the decline in the slope was stronger for men. Consequently, by 2015 women ages 40 to 54 wanted more children than the men in their same age group.

FIGURE 3

AVERAGE PREFERENCE FOR CHILDREN AND OBSERVED NUMBER OF CHILDREN BY AGE GROUP, GENDER AND YEAR. YEARS: 2010 AND 2015

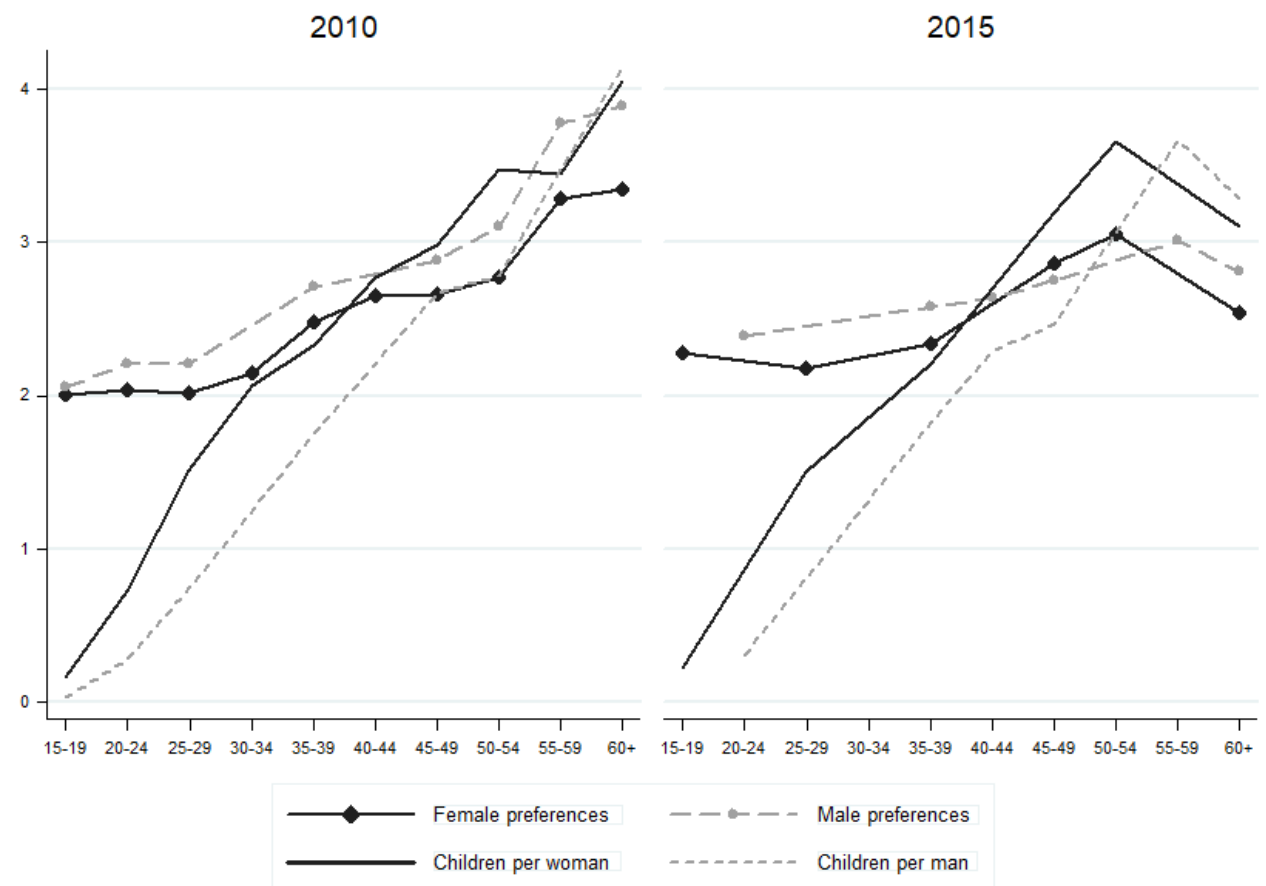

Source: Author's estimates, using data from Centro Centroamericano de Población (2010, 2015). 
Table 1 presents the descriptive statistics for possible correlates of the preferences and demand for children by year and gender in the balanced sample. These include explanatory variables associated with human capital, as in Becker's (1991) and Schultz's (1997) models, as well as seven variables proxying identity, sexuality and contraceptive knowledge, apart from the usual variable identifying female respondents.

TABLE 1

DESCRIPTIVE STATISTICS FOR THE BALANCED SAMPLE, BY GENDER AND YEAR OF SURVEY

\begin{tabular}{|c|c|c|c|c|c|c|}
\hline & \multicolumn{3}{|c|}{2010} & \multicolumn{3}{|c|}{2015} \\
\hline & Total & Female & Male & Total & Female & Male \\
\hline Observations & 2877 & 1448 & 1429 & 2767 & 1447 & 1320 \\
\hline \multicolumn{7}{|l|}{ Dependent variables } \\
\hline Mean desired number of children & 2.54 & 2.42 & 2.65 & 2.51 & 2.44 & 2.57 \\
\hline Mean number of children & 1.73 & 1.93 & 1.54 & 1.80 & 2.04 & 1.53 \\
\hline \multicolumn{7}{|l|}{ Variables on identity } \\
\hline Homophobe scale (average score) & 0.43 & 0.39 & 0.46 & 0.35 & 0.33 & 0.38 \\
\hline \multicolumn{7}{|l|}{ Religion (distribution): } \\
\hline Percentage who is atheist, agnostic or non-believer & 9.5 & 6.8 & 12.2 & 10.0 & 7.0 & 13.3 \\
\hline Percentage who is Catholic & 65.0 & 65.8 & 64.3 & 60.8 & 62.9 & 58.5 \\
\hline Percentage who is non-Catholic Christian & 25.2 & 27.3 & 23.2 & 29.0 & 30.0 & 28.0 \\
\hline Percentage belonging to another religion & 0.2 & 0.2 & 0.3 & 0.2 & 0.1 & 0.2 \\
\hline
\end{tabular}

\section{Variables on sexuality}

Has being in a relationship (distribution):

No relationship (percentage)

$\begin{array}{llllll}36.2 & 31.4 & 41.0 & 33.0 & 27.7 & 38.9 \\ 51.0 & 54.8 & 47.2 & 52.0 & 57.0 & 46.5 \\ 12.8 & 13.7 & 11.8 & 15.0 & 15.3 & 14.6 \\ 17.65 & 18.39 & 16.92 & 17.37 & 17.98 & 16.71\end{array}$

One relationship (percentage)

Average age when first had sex

\begin{tabular}{llllll}
13.0 & 14.0 & 12.1 & 9.4 & 9.5 & 9.3 \\
14.1 & 9.5 & 18.9 & 17.2 & 13.0 & 21.8 \\
34.8 & 31.4 & 38.3 & 38.0 & 35.5 & 40.8 \\
24.3 & 27.6 & 21.1 & 22.6 & 24.9 & 20.1 \\
10.0 & 12.7 & 7.3 & 9.1 & 12.3 & 5.7 \\
3.7 & 5.0 & 2.4 & 3.7 & 4.8 & 2.3 \\
7.9 & 6.4 & 9.4 & 5.6 & 4.8 & 6.4 \\
\hline
\end{tabular}

Age when first had sex (distribution):

Has never had sex (percentage)

Less than 15 years of age (percentage)

Between 15 and 17 years of age (percentage)

Between 18 and 20 years of age (percentage)

Between 21 and 25 years of age (percentage)

Over 25 years of age (percentage)

Percentage of respondents who decides when to have sex

\section{Variables on contraceptive knowledge}

Average number of modern contraceptive methods known

$\begin{array}{llllll}3.6 & 3.9 & 3.4 & 3.4 & 3.2 & 3.5 \\ 9.3 & 9.5 & 9.1 & 8.3 & 11.7 & 4.6 \\ 61.6 & 60.1 & 63.2 & 63.5 & 61.0 & 66.3 \\ 29.1 & 30.5 & 27.7 & 28.2 & 27.4 & 29.1\end{array}$
(percentage) 


\begin{tabular}{|c|c|c|c|c|c|c|}
\hline & \multicolumn{3}{|c|}{2010} & \multicolumn{3}{|c|}{2015} \\
\hline & Total & Female & Male & Total & Female & Male \\
\hline \multicolumn{7}{|l|}{ Human capital (distribution): } \\
\hline Non-qualified (percentage) & 64.1 & 65.0 & 63.3 & 62.0 & 60.7 & 63.3 \\
\hline Semi-qualified (percentage) & 24.1 & 23.4 & 24.7 & 28.2 & 27.7 & 28.8 \\
\hline Qualified (percentage) & 11.8 & 11.6 & 12.0 & 9.8 & 11.5 & 7.9 \\
\hline Percentage who is currently working & 45.1 & 29.1 & 61.3 & 47.5 & 29.9 & 66.9 \\
\hline Percentage who had a child born alive who later died & 5.5 & 6.6 & 4.3 & 5.1 & 5.8 & 4.3 \\
\hline Average number of live-born children who later died & 0.07 & 0.08 & 0.06 & 0.06 & 0.08 & 0.05 \\
\hline $\begin{array}{l}\text { Percentage on professional, managerial, technical } \\
\text { occupation }\end{array}$ & 9.4 & 7.0 & 11.7 & 9.2 & 6.6 & 12.0 \\
\hline Percentage who is self-employed & 12.4 & 8.8 & 16.2 & 13.7 & 6.3 & 21.9 \\
\hline Percentage who works in agriculture & 5.9 & 1.0 & 10.8 & 3.1 & 0.6 & 5.8 \\
\hline Percentage who lives in rural area & 40.5 & 39.9 & 41.0 & 26.8 & 26.0 & 27.7 \\
\hline Percentage who is female & 50.3 & & & 52.3 & & \\
\hline Average age & 35.30 & 35.34 & 35.27 & 35.59 & 36.15 & 34.98 \\
\hline
\end{tabular}

Source: Author's estimates, using data from Centro Centroamericano de Población (2010, 2015).

Identity is proxied through an index measuring homophobia and a categorical variable identifying religious beliefs. The surveys ask people to rate in a four-point Likert scale their agreement with the following ten statements towards homosexual people: "I am uncomfortable to be seen with a gay person", "a gay person should not work with children", "gay people tend to be sexually promiscuous", "it is shocking to see a gay couple kissing", "gay people have typical mannerisms of the opposite sex", "gay people shouldn't be allowed in the same public places as the rest", "a gay person should be able to do any work she chooses", "I can be friends with a gay person", "gay couples should be allowed to adopt children" and "gay civil union should be allowed". The last four statements were coded inversely, and an average of all ten scores was estimated to create a homophobia index ranging from 0 to 1 , where 1 implies the highest level of homophobia. Overall, men score about 6 p.p. higher than women in the index, which might reflect the construction of masculinity and a higher conformity to heteronormativity: while most women (54\%) score below 0.4 , most men (58\%) score above this number.

In contrast, the categorical variable identifying religion might capture non-conformity or conformity to social scripts and roles. About two thirds of the people in the sample identify as Catholics, and about a quarter identifies as non-Catholic Christians, who would be expected to portray more conservative values. Those who are atheist, agnostic or non-believers account for approximately $10 \%$ of the sample population and would be expected to be more liberal in their beliefs and, therefore, would be expected to conform less to socially gendered roles. In both years, men are at least 1.8 times more likely than women to fall into this category. If women are more traditional in their religious beliefs, this could imply stronger cultural barriers to family planning on their part and a greater acceptance of maternal roles, irrespective of their preferences. On the contrary, more liberal people would be expected to have a lower preference for children and to exhibit a more consistent relationship between their preferences and their decisions. In fact, people who are non-religious report both a preference and demand for children lower in about 0.3 children than those who report being religious.

Sexuality is proxied through three variables: two categorical variables measuring whether the person has been in a relationship and the age group when the person first had sex and a binary variable identifying those who believe the decision to have sex is theirs. The number of relationships 
a person has been in provides some information -although scarce- on their history ${ }^{6}$. The data shows that most people (51.5\%) have had only one relationship. This is consistent with a conservative environment where people are expected to mate for life with one single partner. Also, there is a significant difference in the distributions reported by women and men: in 2010, the percentage of women reporting one relationship was 7.7 p.p. higher than that of men and this gap increased to 10.5 p.p. in 2015 . The data also shows that less than $10 \%$ of respondents answer they believe they alone should decide when to have sex. This figure is even lower for women, implying a lack of empowerment regarding their sexuality. At the same time, those women who claim control over their sexual practices report wanting less children (2.2) than the ones who do not control that decision (2.4).

A third variable used to capture how people experience their sexuality refers to the age when the person first became sexually active. For all age groups, women became sexually active at an older age than men. On average, the women in the sample had their first sexual experience at 18, but men became sexually active while still being underaged, around 16 years old. However, the gender gap is narrower in 2015 (1.3 years) than in 2010 (1.5 years), mainly because the age of the first sexual experience has decreased for women more than for men. On average, 3 out of 4 people are sexually active by age 20 and less than 5\% start their sexual activity after 25 years of age. The percentage of respondents with no sexual experience is higher in the 2010 survey (13\%) than in 2015 (9.4\%), which is consistent with a decrease in the age of sexual activity. Figure 4 portrays how younger generations are experiencing sex earlier in life: the generations born in the 1990s and 2000 became sexually active at 16 or earlier. Women, in particular, experienced a steep decline in the age of first sexual activity: from 20 for those born before 1956 to 15.5 for those born after 1995. For men, the decline is not so pronounced and goes from 17.7 years for those born before 1956 to 15.02 for those born between 1996 and 2000. At the same time, people who became sexually active while underaged, tend to have, on average, more children (1.9) than those who initiated their sexual life later (1.6 children).

\section{FIGURE 4 \\ AVERAGE AGE OF FIRST SEXUAL EXPERIENCE BY COHORT AND GENDER}

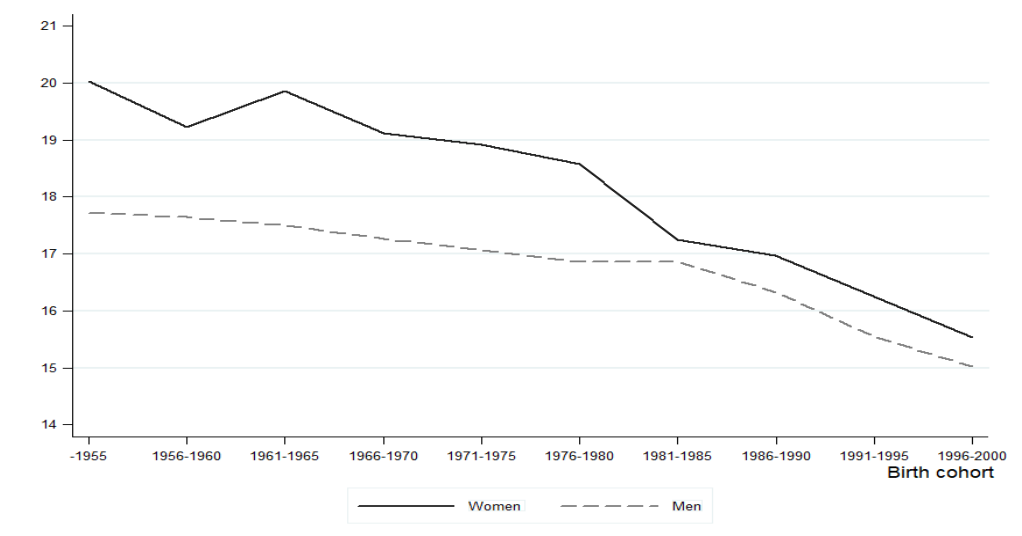

Source: Author's estimates, using data from Centro Centroamericano de Población (2010, 2015).

6 It should be noted that this variable refers to relationships, not sexual partners because the latter was not available. 
The third group of potential correlates of the preferences and demand for children refers to contraceptive knowledge. In the sample, contraceptive knowledge is measured by the number of modern contraceptive methods known and the source from which the person received sex education. On average, both genders claim to know over three contraceptive methods. This suggests that there is some general knowledge about the options available to them and, therefore, that they should know how to control and time their pregnancies. Most respondents also received sex education (91\%), but among those who did not, women represented $62 \%$ of them, making them more vulnerable. And seven out of ten people who received sex education did not obtained it from their preferred source.

The remaining variables in Table 1 are usually associated with the demand for children. These are, in general, quite similar between the 2010 and 2015 balanced samples. A variable measuring education was constructed following the classification used by the Costa Rican Central Bank's Statistical Division (Cicowiez, Sánchez \& Saborío, 2016, p.17), which classifies workers as non-qualified labor if they have a primary education level or less, semi-qualified if they obtained a high school or technical education degree and qualified if they have a university degree. The data shows that almost two thirds of respondents are non-qualified, which is consistent with the national results obtained from other sources. About a quarter of respondents are semi-qualified and about a tenth are qualified. Men are more than twice as likely as women to work: less than $30 \%$ of women in the balanced sample work compared to two thirds of men. Consistent with the literature, women who work exhibit a lower children tenure (1.8) than those who do not (2), but working men have more children (1.7) than those who do not (1.2). But contrary to what is anticipated, the average number of children is not decreasing with the educational level: non-qualified individuals report, on average, two children, this indicator drops to 1.2 for semi-qualified respondents and increases to 1.5 for qualified individuals.

Although most respondents in the balanced sample (94.7\%) have not suffered the loss of a child, those who have exhibit a considerable higher demand for children: an average of 4.9 , that is 3.3 more children than those who have not experienced such a loss. Household income and wealth are also associated with fertility. Unfortunately, these variables are not available. Instead, socioeconomic status is measured through three binary variables identifying whether the person has a professional, managerial or technical occupation, is self-employed and works in agriculture. The first might identify those who have the highest opportunity cost of children: because their income would be related to their work, not their wealth, they would be expected to demand less children. This group only represents $9 \%$ of the balanced sample and is over-represented by men, but has, on average, 1.4 children, compared to 1.8 children of those who do not have such occupations. Similarly, self-employed workers, who are mainly men (70\%), account for $13 \%$ of the sample and have 1.3 times more children than those who are not self-employed, which is consistent with Broussar (2013). And those who work in agriculture, which make up less than $5 \%$ of the sample and are predominantly men (91\%), also have a considerable larger number of children (2) compared to non-farmers (1.7).

The region is also a variable associated with fertility. A binary variable is used to identify whether the person lives in a rural area. Table 1 shows that about $40 \%$ of respondents lived in rural areas in the 2010 sample, but this share decreased to $27 \%$ in 2015 , so that more people are now urban dwellers. Overall, respondents from rural areas do report slightly more children (1.9) than those living in urban areas (1.7), contrasting with Robles and González' (2012a) findings. Finally, $51 \%$ of the sample is female and, on average, respondents are about 35 years old. 


\section{Methods}

Both the desired and actual number of children were estimated using a double hurdle model. In a static model, the demand for children has been traditionally estimated using ordinary least squares in absence of endogeneity or two-stage least squares otherwise (Schultz, 1997). More recently, Poisson or negative binomial models are being used to account for the fact that the dependent variable refers to count data. And, if there are corner solutions, double hurdle models are being used.

The dependent variable in each case is estimated using a double-hurdle model, so that the expected value for the number of children $(c)$ for the individual $j$ is given by:

$$
E\left(c_{j} \mid x_{1 j}, x_{2 j}\right)=\phi\left(x_{1 j} \gamma\right)\left\{x_{2 j} \delta+\sigma \lambda\left(x_{2} \delta / \sigma\right)\right\}
$$

where $x_{1}$ is the matrix of individual characteristics used to estimate a probit model for the probability of having children, $x_{2}$ is the matrix of individual characteristics used in the second stage (to estimate the number of children, given that they have children), $\gamma$ and $\delta$ are the respective coefficient vectors and $\lambda$ is the inverse Mills ratio. In the estimated models, $x_{1}=x_{2}$, which include the variables of interest, i.e., those capturing information on identity, sexuality and contraceptive knowledge described in the previous section, and those referring to the quantity-quality model. All the estimations are presented for women, men and both genders pooled together.

\section{RESULTS}

\section{Preferred number of children}

Table 2 presents the results for the two stages of the double hurdle model for the ideal number of children. Columns 1 to 3 show the coefficient results for the probability of wanting a child, while columns 4 to 6 , the results associated with the preferred number of children. In all cases, the models are different from one with no regressors.

\section{Probability of wanting a child}

Results from the probit estimates show that only a few variables are significantly associated with the probability of wanting a child. Among the variables proxying identity, being atheist, agnostic or non-believer decreases the probability of wanting a child in all cases relative to those who are Catholic, but there is no robust difference observed among Catholics and non-Catholic Christians. For men, being a non-Christian believer increases the probability of wanting to reproduce, relative to being a Catholic. However, the coefficients associated with the homophobe index are not significant at the standard confidence level.

Regarding the variables associated with sexuality, having had a relationship increases the probability of wanting a child for the male and pooled models. Likewise, having had the first sexual experience between 18 and 25 years of age is associated with a higher probability of wanting children for the female and pooled models, while men who delayed the start of their sex life after the age of 25 are more likely to want children, which could suggest more conservative values on their part. Overall, the variables related to contraceptive knowledge are not significantly associated with wanting children except for women who received sexual education from their preferred source 
of information. This result is interesting because it signals that sexual education might not be as relevant if it is not received from a credible and trustful source.

None of the variables proxying human capital or participation in the labor market are significant, which could suggest that the preferences for children are formed independently from the investment schedule on human capital. Similarly, experiencing the death of a child is also not significantly related to the preference for children. As for the variables related to status, being selfemployed increases the odds of wanting a child, while being a female farmer and a male in a rural area decreases them. As expected, women are less likely to want to reproduce. Age also decreases the probability of wanting a child in the female and pooled models, which suggests that the taste for children might vary as the person grows older. Finally, respondents from the 2015 sample are less likely to want to reproduce.

\section{Preferred number of children}

The homophobe index is significantly associated with a desire for more children for men only. This would be as expected, for higher levels of masculinity and heteronormativity would be consistent with a desire for more children. In contrast, the coefficients for being atheist, agnostic or non-believer exhibit the expected negative sign, but they are only significant at the standard confidence levels for the pooled sample. The latter suggests that being atheist, agnostic or nonbeliever is related to the initial preference for wanting children, but not so much in determining the ideal number of children wanted. Also, non-Christian women prefer less children than Catholic ones.

Concerning the variables related to sexuality, the results suggest that the number of desired children are increasing with the number of relationships a person has for the male and pooled samples: men with one relationship prefer $36.6 \%$ more children than men who have never experienced a relationship and men with two or more partners prefer $42.6 \%$ more children than men in the reference category. Becoming sexually active later in life is also significant for women: those who had their first sexual experience after the age of 25 prefer $31.4 \%$ less children than those who became sexually active at 15-17 years old. Also, women who believe they are the ones who decide when to have sex desire $24.0 \%$ fewer children than women who do not. Finally, none of the variables associated with contraceptive knowledge are significant, at the standard confidence level.

Neither the variable measuring human capital nor the variable indicating whether the person works are significant. As expected, having lost a child is positively related to a higher preference for children for the pooled and female models: women who have lost a child prefer $24.4 \%$ more children than those who have not, while the difference observed in the pooled model is only of $21.0 \%$. Age is also significantly related to a larger number of preferred children for women. As expected, having a professional, managerial or technical occupation decreases the preferred number of children by $19.7 \%$ in men compared to the reference group. Living in a rural area is positively associated with desiring more children in all three models, suggesting that the cost of having children is presumably lower in these areas. Women's optimal number of children is $18.9 \%$ lower than the number of children wanted by men, ceteris paribus (column 4). And finally, respondents from the 2015 survey prefer, on average, 9.8\% more children than respondents from the 2010 survey. 
TABLE 2

DOUBLE HURDLE REGRESSION RESULTS FOR THE PREFERRED NUMBER OF CHILDREN, BY GENDER (ROBUST STANDARD ERRORS)

\begin{tabular}{|c|c|c|c|c|c|c|c|c|c|c|c|c|}
\hline \multirow{4}{*}{ Homophobe index } & \multicolumn{6}{|c|}{ Probit for wanting a child } & \multicolumn{6}{|c|}{ Preferred number of children } \\
\hline & \multicolumn{2}{|c|}{ 1. Pooled } & \multicolumn{2}{|c|}{ 2. Female } & \multicolumn{2}{|c|}{ 3. Male } & \multicolumn{2}{|c|}{ 4. Pooled } & \multicolumn{2}{|c|}{ 5. Female } & \multicolumn{2}{|c|}{ 6. Male } \\
\hline & -0.108 & & -0.193 & & -0.029 & & 0.126 & & -0.105 & & 0.348 & * \\
\hline & $(0.160)$ & & $(0.215)$ & & $(0.247)$ & & $(0.134)$ & & $(0.199)$ & & $(0.183)$ & \\
\hline \multicolumn{13}{|l|}{$\begin{array}{l}\text { Religion (reference }= \\
\text { Catholics) }\end{array}$} \\
\hline \multirow{2}{*}{$\begin{array}{l}\text { Is atheist, agnostic or non- } \\
\text { believer }\end{array}$} & -0.307 & & -0.342 & $* * *$ & -0.306 & $* * *$ & -0.175 & $* *$ & -0.199 & & -0.165 & \\
\hline & $(0.087)$ & & $(0.132)$ & & $(0.118)$ & & $(0.081)$ & & $(0.127)$ & & $(0.104)$ & \\
\hline \multirow[t]{2}{*}{ Non-Catholic Christian } & -0.046 & & 0.025 & & -0.106 & & 0.016 & & 0.010 & & 0.009 & \\
\hline & $(0.065)$ & & $(0.086)$ & & $(0.099)$ & & $(0.056)$ & & $(0.074)$ & & $(0.083)$ & \\
\hline \multirow[t]{2}{*}{ Other religion } & -0.327 & & -0.788 & & 3.093 & $* * *$ & -0.028 & & -1.555 & $* * *$ & 0.648 & \\
\hline & $(0.530)$ & & $(0.703)$ & & $(0.154)$ & & $(0.953)$ & & $(0.509)$ & & $(1.257)$ & \\
\hline \multicolumn{13}{|l|}{$\begin{array}{l}\text { Has being in a relationship } \\
\text { (reference }=\text { no) }\end{array}$} \\
\hline \multirow[t]{2}{*}{ One partner } & 0.198 & $* *$ & 0.169 & & 0.254 & $* *$ & 0.203 & $* * *$ & 0.102 & & 0.312 & $* * *$ \\
\hline & $(0.078)$ & & $(0.109)$ & & $(0.120)$ & & $(0.059)$ & & $(0.080)$ & & $(0.086)$ & \\
\hline \multirow[t]{2}{*}{ More than one partner } & 0.196 & * & 0.074 & & 0.442 & $* * *$ & 0.239 & $* * *$ & 0.097 & & 0.355 & $* * *$ \\
\hline & $(0.103)$ & & $(0.138)$ & & $(0.170)$ & & $(0.092)$ & & $(0.123)$ & & $(0.136)$ & \\
\hline \multicolumn{13}{|l|}{$\begin{array}{l}\text { Age when first had sex (ref. = } \\
15-17 \text { years old) }\end{array}$} \\
\hline \multirow[t]{2}{*}{ Has never had sex } & -0.029 & & 0.045 & & -0.151 & & & & & & & \\
\hline & $(0.107)$ & & $(0.151)$ & & $(0.154)$ & & & & & & & \\
\hline \multirow[t]{2}{*}{ Less than 15 years of age } & 0.029 & & -0.097 & & 0.116 & & 0.097 & & 0.179 & & 0.071 & \\
\hline & $(0.082)$ & & $(0.117)$ & & $(0.116)$ & & $(0.075)$ & & $(0.126)$ & & $(0.095)$ & \\
\hline \multirow[t]{2}{*}{ Between 18 and 20 years of age } & 0.164 & $* *$ & $0.173^{*}$ & & 0.172 & & -0.012 & & -0.104 & & 0.087 & \\
\hline & $(0.074)$ & & $(0.099)$ & & $(0.116)$ & & $(0.062)$ & & $(0.083)$ & & $(0.092)$ & \\
\hline \multirow[t]{2}{*}{ Between 21 and 25 years of age } & 0.255 & & 0.312 & $* *$ & 0.145 & & -0.015 & & -0.119 & & 0.116 & \\
\hline & $(0.104)$ & & $(0.131)$ & & $(0.179)$ & & $(0.087)$ & & $(0.111)$ & & $(0.142)$ & \\
\hline \multirow[t]{2}{*}{ Over 25 years of age } & 0.200 & & 0.094 & & 0.766 & $*$ & -0.216 & & -0.377 & $* *$ & 0.032 & \\
\hline & $(0.143)$ & & $(0.166)$ & & $(0.396)$ & & $(0.141)$ & & $(0.167)$ & & $(0.252)$ & \\
\hline \multirow{2}{*}{$\begin{array}{l}\text { Respondent decides when to } \\
\text { have sex }\end{array}$} & -0.128 & & -0.193 & & -0.063 & & -0.200 & ** & -0.275 & ** & -0.169 & \\
\hline & $(0.103)$ & & $(0.145)$ & & $(0.150)$ & & $(0.099)$ & & $(0.137)$ & & $(0.140)$ & \\
\hline Number of modern & -0.009 & & -0.022 & & 0.005 & & -0.008 & & -0.006 & & -0.011 & \\
\hline & $(0.014)$ & & $(0.022)$ & & $(0.019)$ & & $(0.013)$ & & $(0.019)$ & & $(0.017)$ & \\
\hline $\begin{array}{l}\text { Source of sex education (ref. = } \\
\text { did not receive) }\end{array}$ & & & & & & & & & & & & \\
\hline Received sex ed., but not from & -0.002 & & 0.069 & & -0.124 & & 0.052 & & -0.008 & & 0.154 & \\
\hline & $(0.099)$ & & $(0.119)$ & & $(0.188)$ & & $(0.089)$ & & $(0.120)$ & & $(0.130)$ & \\
\hline Received sex ed., from & -0.175 & & $-0.226^{*}$ & & -0.171 & & 0.078 & & 0.065 & & 0.152 & \\
\hline & $(0.109)$ & & $(0.134)$ & & $(0.202)$ & & $(0.096)$ & & $(0.129)$ & & $(0.140)$ & \\
\hline $\begin{array}{l}\text { Human capital (ref.= non- } \\
\text { qualified) }\end{array}$ & & & & & & & & & & & & \\
\hline Semi-qualified & 0.029 & & 0.049 & & -0.029 & & 0.023 & & -0.049 & & 0.120 & \\
\hline & $(0.069)$ & & $(0.094)$ & & $(0.101)$ & & $(0.056)$ & & $(0.074)$ & & $(0.085)$ & \\
\hline
\end{tabular}




\begin{tabular}{|c|c|c|c|c|c|c|c|c|c|c|c|c|}
\hline & \multicolumn{6}{|c|}{ Probit for wanting a child } & \multicolumn{6}{|c|}{ Preferred number of children } \\
\hline & \multicolumn{2}{|c|}{ 1. Pooled } & \multicolumn{2}{|c|}{ 2. Female } & \multicolumn{2}{|c|}{ 3. Male } & \multicolumn{2}{|c|}{ 4. Pooled } & \multicolumn{2}{|c|}{ 5. Female } & \multicolumn{2}{|c|}{ 6. Male } \\
\hline \multirow[t]{2}{*}{ Qualified } & -0.095 & & -0.041 & & -0.248 & & -0.016 & & -0.047 & & 0.041 & \\
\hline & $(0.104)$ & & $(0.143)$ & & $(0.165)$ & & $(0.083)$ & & $(0.110)$ & & $(0.127)$ & \\
\hline \multirow[t]{2}{*}{ Currently works } & 0.050 & & 0.104 & & -0.048 & & -0.054 & & -0.129 & & 0.036 & \\
\hline & $(0.071)$ & & $(0.102)$ & & $(0.110)$ & & $(0.060)$ & & $(0.087)$ & & $(0.088)$ & \\
\hline \multirow{2}{*}{$\begin{array}{l}\text { Number of live born children } \\
\text { who later died }\end{array}$} & 0.128 & & 0.171 & & 0.022 & & 0.236 & $* *$ & 0.280 & $* *$ & 0.150 & \\
\hline & $(0.101)$ & & $(0.139)$ & & $(0.134)$ & & $(0.097)$ & & $(0.118)$ & & $(0.169)$ & \\
\hline \multirow{2}{*}{$\begin{array}{l}\text { Professional, managerial, } \\
\text { technical occupation }\end{array}$} & -0.053 & & -0.064 & & -0.041 & & -0.158 & * & -0.054 & & -0.219 & * \\
\hline & $(0.119)$ & & $(0.193)$ & & $(0.160)$ & & $(0.092)$ & & $(0.136)$ & & $(0.123)$ & \\
\hline \multirow[t]{2}{*}{ Self-employ } & 0.142 & & 0.007 & & $0.224^{*}$ & & 0.078 & & 0.145 & & 0.066 & \\
\hline & $(0.097)$ & & $(0.156)$ & & $(0.128)$ & & $(0.077)$ & & $(0.128)$ & & $(0.098)$ & \\
\hline \multirow[t]{2}{*}{ Works in agriculture } & -0.157 & & -0.656 & $* *$ & -0.059 & & -0.022 & & -0.354 & & 0.002 & \\
\hline & $(0.140)$ & & $(0.316)$ & & $(0.164)$ & & $(0.117)$ & & $(0.384)$ & & $(0.127)$ & \\
\hline \multirow[t]{2}{*}{ Rural area } & -0.042 & & 0.061 & & $-0.151^{*}$ & $*$ & 0.144 & $* * *$ & 0.128 & $*$ & 0.142 & $*$ \\
\hline & $(0.059)$ & & $(0.078)$ & & $(0.091)$ & & $(0.052)$ & & $(0.071)$ & & $(0.076)$ & \\
\hline \multirow[t]{2}{*}{ Is female } & -0.233 & $* * *$ & & & & & -0.209 & $* * *$ & & & & \\
\hline & $(0.063)$ & & & & & & $(0.052)$ & & & & & \\
\hline \multirow[t]{2}{*}{ Age } & -0.027 & $* *$ & -0.042 & $* * *$ & -0.010 & & 0.004 & & 0.032 & $* *$ & -0.026 & \\
\hline & $(0.012)$ & & $(0.015)$ & & $(0.018)$ & & $(0.012)$ & & $(0.015)$ & & $(0.018)$ & \\
\hline \multirow[t]{2}{*}{ Age squared } & 0.000 & & 0.000 & $*$ & -0.000 & & 0.000 & $* *$ & 0.000 & & 0.001 & $* * *$ \\
\hline & $(0.000)$ & & $(0.000)$ & & $(0.000)$ & & $(0.000)$ & & $(0.000)$ & & $(0.000)$ & \\
\hline \multirow[t]{2}{*}{2015 survey } & -0.251 & $* * *$ & -0.123 & & -0.433 & $* * *$ & 0.103 & $* *$ & 0.078 & & 0.113 & \\
\hline & $(0.058)$ & & $(0.078)$ & & $(0.090)$ & & $(0.049)$ & & $(0.068)$ & & $(0.069)$ & \\
\hline \multirow[t]{2}{*}{ Constant } & 2.516 & $* * *$ & 2.549 & $* * *$ & 2.403 & $* * *$ & 1.665 & $* * *$ & 1.238 & $* * *$ & 1.862 & $* * *$ \\
\hline & $(0.249)$ & & $(0.324)$ & & $(0.387)$ & & $(0.209)$ & & $(0.273)$ & & $(0.310)$ & \\
\hline \multirow[t]{2}{*}{ Constant alpha } & & & & & & & 1.516 & $* * *$ & 1.477 & $* * *$ & 1.545 & $* * *$ \\
\hline & & & & & & & $(0.042)$ & & $(0.054)$ & & $(0.064)$ & \\
\hline Observations & & & & & & & 5644 & & 2895 & & 2749 & \\
\hline F statistic & & & & & & & 90.143 & & 57.926 & & 1113.725 & \\
\hline Prob $>$ F & & & & & & & 0.000 & & 0.000 & & 0.000 & \\
\hline
\end{tabular}

$* p<0.10, * * p<0.05, * * * p<0.01$

Source: Author's estimates, using data from Centro Centroamericano de Población (2010, 2015).

\section{Demand for children}

Table 3 presents the results for the double hurdle model. The first section presents the regression results for having a child. The second part presents the results for the number of children given that the individual has a child. As before, all the models are different from one with no regressors. For simplicity, both sections of table 3 are discussed separately in the following sections.

\section{Probability of having a child}

The probability of having a child is negatively related to being atheist, agnostic or non-believer and positively and significantly related to the number of relationships the individual has experienced, 
which is similar to the previous findings, but the coefficients are now significant in all cases Obviously, the probability of having a child is negatively associated with not being sexually active ${ }^{7}$. For the female and pooled samples, becoming sexually active after the age of 25 is associated with a lower probability of reproducing. But the most relevant results between this model and the previous one is that having a taste for children seem to be correlated with different variables than the decision to have children. In the latter, variables related to human capital, attachment to the labor market, contraceptive knowledge and experiencing the death of a child are significant. While contraceptive knowledge was not significant in explaining the taste for children, it is significant in explaining the probability of having a child in the pooled and female samples. The positive sign associated with this coefficient is counterintuitive, but it probably suggests that women with children are more likely to be interested in learning about contraception. Likewise, receiving sexual education, regardless of the source, decreases the probability of reproduction in all the samples, presumably by providing information and means for people to adjust their reproductive decisions to their preferences. Further, the effect is stronger when the education was provided by the preferred source, maybe because people would be more receptive to the information in such case.

A relevant difference between the model estimating the probability of wanting children and the one at hand is that in the latter the coefficients associated with human capital are significant: the probability of reproducing is decreasing with human capital in the pooled and female models. The attachment women and men have with the labor market relates differently with the odds of having a child: while working women are less likely to have a child, working men are more likely to do so. And, having a professional, managerial or technical occupation is negatively associated with the probability of reproducing for men, suggesting that men in these high-status occupations have a different taste for children. This would be expected, given their higher opportunity cost.

The results also show that the probability of having a child increases at a decreasing rate with age (i.e., the coefficient associated with age is positive but the one associated with age squared is negative). This would be expected, given that age has been associated with increasing psychological costs of childrearing (Mc Donald, 2002) and that, since the introduction of the pill, women have been able to postpone the age of their first pregnancy and control their pregnancies. Finally, pooled respondents from the 2015 survey are more likely to have a child, at the $95 \%$ confidence level, even though they were less likely to want to have them.

\section{Demand for children}

Columns 4 to 6 present the coefficient results for the second stage of the hurdle model estimates. The homophobe index is still not significant. And while not being religious was key in deciding to reproduce, it is not significantly associated with the number of children had. In contrast, non-Catholic Christians demand 23\% more children than Catholics, with non-Catholic Christian men demanding even more children (27.6\%) than Catholic men, at a $90 \%$ confidence level. The number of children increases with the number of relationships the person had for the pooled, female and male models. And it is somehow alarming that people who became sexually active before age 15 have a larger descendance. One of the most interesting results of this model is that, while deciding when to have sex was negatively related to the female preferences for children, this variable is not related to the number of children. This points to an imbalance of power: even women who are in control of their sexuality are not efficient in negotiating their reproductive

7 These results were estimated with the balanced sample. Results do not vary significantly if they are estimated with a subsample consisting of only those people who are sexually active. 
decisions in line with their fewer preference for children. Both variables of contraceptive knowledge are significant in the pooled sample at the standard confidence level: on average, knowing an additional contraceptive method increases the difference in the logs of the expected children by 0.036 children. Similarly, having received sex education reduces the number of children in the pooled and female samples, even more so if it was received from the preferred source.

The results on human capital are quite interesting: while the variable is significant in all cases, it is not decreasing for men, as one would expect. For example, semi-qualified men demand $36.0 \%$ less children than non-qualified men, but qualified men only demand $28.4 \%$ less children than the reference group. This means that qualified men are demanding more children than the semi-qualified ones, which is consistent with Hazan and Zoabi's (2015) argument that people who can afford high-quality children might start demanding more of them if they are able to afford them. As predicted by the model, working reduces the number of children in the female and pooled samples; and the loss of a child and living in a rural area increase it in all cases. Women demand $20 \%$ less children than men. The number of children also increases at a decreasing rate with age and there is no significant difference between the 2010 and 2015 surveys.

TABLE 3 DOUBLE HURDLE REGRESSION RESULTS FOR THE NUMBER OF CHILDREN, BY GENDER
(ROBUST STANDARD ERRORS)

\begin{tabular}{|c|c|c|c|c|c|c|c|c|c|c|c|c|}
\hline & \multicolumn{6}{|c|}{ Probit for wanting a child } & \multicolumn{6}{|c|}{ Preferred number of children } \\
\hline & \multicolumn{2}{|c|}{ 1. Pooled } & \multicolumn{2}{|c|}{ 2. Female } & \multicolumn{2}{|c|}{ 3. Male } & \multicolumn{2}{|c|}{ 4. Pooled } & \multicolumn{2}{|c|}{ 5. Female } & \multicolumn{2}{|c|}{ 6. Male } \\
\hline Homophobe index & $\begin{array}{l}-0.000 \\
(0.147)\end{array}$ & & $\begin{array}{l}0.198 \\
(0.230)\end{array}$ & & $\begin{array}{l}-0.118 \\
(0.194)\end{array}$ & & $\begin{array}{l}0.020 \\
(0.180)\end{array}$ & & $\begin{array}{l}-0.040 \\
(0.220)\end{array}$ & & $\begin{array}{l}0.203 \\
(0.304)\end{array}$ & \\
\hline $\begin{array}{l}\text { Religion (reference }= \\
\text { Catholics) }\end{array}$ & & & & & & & & & & & & \\
\hline $\begin{array}{l}\text { Is atheist, agnostic or non- } \\
\text { believer }\end{array}$ & $\begin{array}{l}-0.259 \\
(0.081)\end{array}$ & $* * *$ & $\begin{array}{l}-0.334 \\
(0.131)\end{array}$ & $* *$ & $\begin{array}{l}-0.224 \\
(0.106)\end{array}$ & $* *$ & $\begin{array}{l}0.080 \\
(0.122)\end{array}$ & & $\begin{array}{l}0.165 \\
(0.150)\end{array}$ & & $\begin{array}{l}0.024 \\
(0.191)\end{array}$ & \\
\hline Non-Catholic Christian & $\begin{array}{l}-0.103 \\
(0.061)\end{array}$ & $*$ & $\begin{array}{l}-0.120 \\
(0.089)\end{array}$ & & $\begin{array}{l}-0.134 \\
(0.087)\end{array}$ & & $\begin{array}{l}0.208 \\
(0.072)\end{array}$ & $* * *$ & $\begin{array}{l}0.160 \\
(0.086)\end{array}$ & $* * *$ & $\begin{array}{l}0.244 \\
(0.127)\end{array}$ & * \\
\hline Other religion & $\begin{array}{l}-0.467 \\
(0.394) \\
\end{array}$ & & $\begin{array}{l}-0.648 \\
(0.546) \\
\end{array}$ & & $\begin{array}{l}-0.220 \\
(0.543) \\
\end{array}$ & & $\begin{array}{l}-0.835 \\
(0.458) \\
\end{array}$ & $*$ & $\begin{array}{l}-0.417 \\
(0.855) \\
\end{array}$ & & $\begin{array}{l}-0.989 \\
(0.591)\end{array}$ & * \\
\hline $\begin{array}{l}\text { Has being in a relationship } \\
\text { (reference = no) }\end{array}$ & & & & & & & & & & & & \\
\hline One partner & $\begin{array}{l}1.404 \\
(0.058)\end{array}$ & $* * *$ & $\begin{array}{l}1.194 \\
(0.085)\end{array}$ & $* * *$ & $\begin{array}{l}1.570 \\
(0.083)\end{array}$ & $* * *$ & $\begin{array}{l}0.483 \\
(0.117)\end{array}$ & $* * *$ & $\begin{array}{l}0.395 \\
(0.132)\end{array}$ & $* * *$ & $\begin{array}{l}0.661 \\
(0.230)\end{array}$ & $* * *$ \\
\hline More than one partner & $\begin{array}{l}1.611 \\
(0.093) \\
\end{array}$ & $* * *$ & $\begin{array}{l}1.380 \\
(0.147) \\
\end{array}$ & $* * *$ & $\begin{array}{l}1.750 \\
(0.125) \\
\end{array}$ & $* * *$ & $\begin{array}{l}1.006 \\
(0.137)\end{array}$ & $* * *$ & $\begin{array}{l}0.820 \\
(0.155) \\
\end{array}$ & $* * *$ & $\begin{array}{l}1.259 \\
(0.261) \\
\end{array}$ & $* * *$ \\
\hline $\begin{array}{l}\text { Age when first had sex (ref. } \\
=15-17 \text { years old) }\end{array}$ & & & & & & & & & & & & \\
\hline Has never had sex & $\begin{array}{l}-6.918 \\
(0.174)\end{array}$ & $* * *$ & $\begin{array}{l}-6.959 \\
(0.260)\end{array}$ & $* * *$ & $\begin{array}{l}-6.604 \\
(0.311)\end{array}$ & $* * *$ & & & & & & \\
\hline Less than 15 years of age & $\begin{array}{l}0.097 \\
(0.074)\end{array}$ & & $\begin{array}{l}0.246 \\
(0.129)\end{array}$ & $*$ & $\begin{array}{l}0.070 \\
(0.095)\end{array}$ & & $\begin{array}{l}0.318 \\
(0.094)\end{array}$ & $* * *$ & $\begin{array}{l}0.442 \\
(0.126)\end{array}$ & $* * *$ & $\begin{array}{l}0.246 \\
(0.143)\end{array}$ & * \\
\hline $\begin{array}{l}\text { Between } 18 \text { and } 20 \text { years } \\
\text { of age }\end{array}$ & $\begin{array}{l}-0.083 \\
(0.065)\end{array}$ & & $\begin{array}{l}-0.264 \\
(0.100)\end{array}$ & $* * *$ & $\begin{array}{l}0.062 \\
(0.089)\end{array}$ & & $\begin{array}{l}-0.253 \\
(0.078)\end{array}$ & $* * *$ & $\begin{array}{l}-0.374 \\
(0.092)\end{array}$ & $* * *$ & $\begin{array}{l}-0.117 \\
(0.138)\end{array}$ & \\
\hline $\begin{array}{l}\text { Between } 21 \text { and } 25 \text { years } \\
\text { of age }\end{array}$ & $\begin{array}{l}0.008 \\
(0.097)\end{array}$ & & $\begin{array}{l}-0.216 \\
(0.141)\end{array}$ & & $\begin{array}{l}0.213 \\
(0.143)\end{array}$ & & $\begin{array}{l}-0.512 \\
(0.098)\end{array}$ & $* * *$ & $\begin{array}{l}-0.747 \\
(0.117)\end{array}$ & $* * *$ & $\begin{array}{l}-0.064 \\
(0.176)\end{array}$ & \\
\hline Over 25 years of age & $\begin{array}{l}-0.627 \\
(0.141)\end{array}$ & $* * *$ & $\begin{array}{l}-1.013 \\
(0.185)\end{array}$ & $* * *$ & $\begin{array}{l}0.021 \\
(0.221)\end{array}$ & & $\begin{array}{l}-1.140 \\
(0.172)\end{array}$ & $* * *$ & $\begin{array}{l}-1.365 \\
(0.204)\end{array}$ & $* * *$ & $\begin{array}{l}-0.717 \\
(0.295)\end{array}$ & $* *$ \\
\hline
\end{tabular}




\begin{tabular}{|c|c|c|c|c|c|c|c|c|c|c|c|c|}
\hline \multirow{4}{*}{$\begin{array}{l}\text { Respondent decides when } \\
\text { to have sex }\end{array}$} & \multicolumn{6}{|c|}{ Probit for wanting a child } & \multicolumn{6}{|c|}{ Preferred number of children } \\
\hline & \multicolumn{2}{|c|}{ 1. Pooled } & \multicolumn{2}{|c|}{ 2. Female } & \multicolumn{2}{|c|}{ 3. Male } & \multicolumn{2}{|c|}{ 4. Pooled } & \multicolumn{2}{|c|}{ 5. Female } & \multicolumn{2}{|c|}{ 6. Male } \\
\hline & -0.078 & & -0.175 & & -0.090 & & 0.061 & & -0.061 & & 0.139 & \\
\hline & $(0.098)$ & & $(0.152)$ & & $(0.129)$ & & $(0.121)$ & & $(0.154)$ & & $(0.185)$ & \\
\hline \multirow{2}{*}{$\begin{array}{l}\text { Number of modern } \\
\text { contraceptive methods } \\
\text { known }\end{array}$} & 0.035 & $* * *$ & 0.058 & $* *$ & 0.020 & & 0.036 & $* *$ & 0.028 & & 0.041 & $*$ \\
\hline & $(0.013)$ & & $(0.024)$ & & $(0.017)$ & & $(0.016)$ & & $(0.022)$ & & $(0.025)$ & \\
\hline \multicolumn{13}{|l|}{$\begin{array}{l}\text { Source of sex education } \\
\text { (ref. = did not receive) }\end{array}$} \\
\hline \multirow{2}{*}{$\begin{array}{l}\text { Received sex ed., but not } \\
\text { from preferred source }\end{array}$} & -0.418 & $* * *$ & -0.397 & $* * *$ & -0.393 & $* *$ & -0.311 & $* * *$ & -0.305 & $* * *$ & -0.299 & \\
\hline & $(0.113)$ & & $(0.159)$ & & $(0.168)$ & & $(0.103)$ & & $(0.113)$ & & $(0.209)$ & \\
\hline \multirow{2}{*}{$\begin{array}{l}\text { Received sex ed., from } \\
\text { preferred source }\end{array}$} & -0.611 & $* * *$ & -0.673 & $* * *$ & -0.504 & $* * *$ & -0.409 & $* * *$ & -0.351 & $* * *$ & -0.435 & $*$ \\
\hline & $(0.119)$ & & $(0.167)$ & & $(0.179)$ & & $(0.118)$ & & $(0.128)$ & & $(0.242)$ & \\
\hline \multicolumn{13}{|l|}{$\begin{array}{l}\text { Human capital (ref.= non- } \\
\text { qualified) }\end{array}$} \\
\hline \multirow[t]{2}{*}{ Semi-qualified } & -0.168 & $* * *$ & -0.322 & $* * *$ & -0.018 & & -0.443 & $* * *$ & -0.403 & $* * *$ & -0.446 & $* * *$ \\
\hline & $(0.062)$ & & $(0.092)$ & & $(0.087)$ & & $(0.075)$ & & $(0.086)$ & & $(0.132)$ & \\
\hline \multirow[t]{2}{*}{ Qualified } & -0.443 & $* * *$ & -0.659 & $* * *$ & -0.191 & & -0.553 & $* * *$ & -0.673 & $* * *$ & -0.334 & $*$ \\
\hline & $(0.091)$ & & $(0.134)$ & & $(0.124)$ & & $(0.113)$ & & $(0.137)$ & & $(0.194)$ & \\
\hline \multirow[t]{2}{*}{ Currently works } & 0.055 & & -0.225 & $* *$ & 0.378 & *** & -0.254 & *** & -0.367 & $* * *$ & 0.064 & \\
\hline & $(0.068)$ & & $(0.104)$ & & $(0.096)$ & & $(0.078)$ & & $(0.094)$ & & $(0.148)$ & \\
\hline \multirow{2}{*}{$\begin{array}{l}\text { Number of live born } \\
\text { children who later died }\end{array}$} & 4.812 & $* * *$ & 4.465 & $* * *$ & 4.652 & $* * *$ & 1.135 & $* * *$ & 1.119 & $* * *$ & 1.119 & $* * *$ \\
\hline & $(0.095)$ & & $(0.119)$ & & $(0.151)$ & & $(0.082)$ & & $(0.114)$ & & $(0.112)$ & \\
\hline \multirow{2}{*}{$\begin{array}{l}\text { Professional, managerial, } \\
\text { technical occupation }\end{array}$} & -0.104 & & 0.089 & & -0.245 & $* *$ & -0.067 & & 0.191 & & -0.282 & \\
\hline & $(0.095)$ & & $(0.156)$ & & $(0.120)$ & & $(0.124)$ & & $(0.169)$ & & $(0.178)$ & \\
\hline \multirow[t]{2}{*}{ Self-employ } & -0.076 & & 0.014 & & -0.120 & & 0.114 & & 0.018 & & 0.160 & \\
\hline & $(0.080)$ & & $(0.157)$ & & $(0.095)$ & & $(0.096)$ & & $(0.137)$ & & $(0.135)$ & \\
\hline \multirow[t]{2}{*}{ Works in agriculture } & 0.016 & & -0.001 & & -0.017 & & 0.138 & & 0.099 & & 0.062 & \\
\hline & $(0.126)$ & & $(0.518)$ & & $(0.137)$ & & $(0.137)$ & & $(0.313)$ & & $(0.166)$ & \\
\hline Rural area & 0.014 & & -0.024 & & 0.037 & & 0.198 & $* * *$ & 0.172 & $* *$ & 0.205 & $*$ \\
\hline & $(0.058)$ & & $(0.087)$ & & $(0.081)$ & & $(0.068)$ & & $(0.080)$ & & $(0.119)$ & \\
\hline Is female & 0.777 & **** & & & & & 0.230 & **** & & & & \\
\hline & $(0.060)$ & & & & & & $(0.073)$ & & & & & \\
\hline Age & 0.154 & **** & 0.200 & $* * *$ & 0.124 & $* * *$ & 0.163 & **** & 0.189 & **** & 0.125 & **** \\
\hline & $(0.011)$ & & $(0.017)$ & & $(0.014)$ & & $(0.016)$ & & $(0.019)$ & & $(0.029)$ & \\
\hline Age squared & -0.001 & $* * *$ & -0.002 & $* * *$ & -0.001 & $* * *$ & -0.001 & $* * *$ & -0.001 & $* * *$ & -0.000 & \\
\hline & $(0.000)$ & & $(0.000)$ & & $(0.000)$ & & $(0.000)$ & & $(0.000)$ & & $(0.000)$ & \\
\hline 2015 survey & 0.110 & $* *$ & 0.140 & $*$ & 0.102 & & -0.064 & & -0.107 & & -0.023 & \\
\hline & $(0.055)$ & & $(0.084)$ & & $(0.075)$ & & $(0.063)$ & & $(0.078)$ & & $(0.108)$ & \\
\hline Constant & -3.653 & **** & -3.370 & $* * *$ & -3.587 & $* * *$ & -2.883 & **** & -2.769 & **** & -2.971 & $* * *$ \\
\hline & $(0.223)$ & & $(0.332)$ & & $(0.310)$ & & $(0.374)$ & & $(0.416)$ & & $(0.705)$ & \\
\hline Constant alpha & & & & & & & 1.575 & **** & 1.451 & $* * *$ & 1.716 & **** \\
\hline & & & & & & & $(0.039)$ & & $(0.044)$ & & $(0.068)$ & \\
\hline Observations & & & & & & & 5644 & & 2895 & & 2749 & \\
\hline F statistic & & & & & & & 7053.806 & & 5883.147 & & 3081.616 & \\
\hline Prob $>$ F & & & & & & & 0.000 & & 0.000 & & 0.000 & \\
\hline
\end{tabular}

$* p<0.10, * * p<0.05, * * * p<0.01$

Source: Author's estimates, using data from Centro Centroamericano de Población (2010, 2015). 


\section{DISCUSSION AND CONCLUSIONS}

The paper presents estimates for the number of preferred and effectively had children in Costa Rica by individuals over 15 years of age. The data shows that, by large, the optimal number of desired children is 2 , which is consistent with the two-child psychology hypothesis. On average, men desire more children than women, which is expected because women carry the costs of reproduction. A stronger male preference for children comes as no surprise, since Costa Rica is a very conservative country, with a constitutional Catholic State and a marked patriarchal hierarchy. In such contexts, a wide descendance is a sign of masculinity and male power and, thus, optimal from a male perspective. Meanwhile, the cost of household work and child-rearing is assumed by women: in Costa Rica, women spend more than two hours a day cleaning, cooking and doing laundry, compared with 20 minutes by men; and by age 30 women are spending a similar amount of time in caring activities, 2.7 times that spend by men on such tasks (Jiménez-Fontana, 2015). Women are also faced with higher opportunity costs and risks associated with reproduction: $35 \%$ of births are from women who do not have or live with their partners (INEC, n.d.), which increases their risks of lower income and higher inequality (Kasy and Ramos, 2014). Hence, it would be expected for women to exhibit a lower preference for children as, in fact, is the case.

In addition, the share of the population who would prefer to be childless has slightly increased over time along with those who would rather have numerous families. As a result, the mean desired number of children has remained quite stable around 2.5 children. Because preferences seem so fixed around this number, only a few variables are significant in explaining them. These include having multiple partners and child mortality. The loss of a child is not associated with having a taste for children, but it is related to the desired number of children, particularly for women, while the number of relationships had is related to both wanting children and the ideal family size. These are both variables that can be associated with genetic arguments: people might be either replacing or hoarding children under uncertainty of their survival; at the same time, if people who establish more relationships are also more likely to reproduce, their chances of bettering their genes and passing them on are also improved.

Cultural and socio-economic variables are not as robust in explaining the preferences for children except for being a woman and not being religious. Women prefer fewer children than men, probably because they are aware of the burdens imposed on them by reproduction and parenting. Likewise, because non-religious people do not have to comply to the patriarchal and obedient framework imposed by religion, they might be more self-aware of their own preferences rather than the scripts expected of them by society. In a country like Costa Rica, this is not a trivial matter, since religion has historically been a decisive factor in preventing full reproductive rights for women, so being non-religious may reflect a more liberal set of values. Consequently, being nonreligious is crucial in not developing a taste for children, but not in deciding the ideal family once the decision to reproduce is made.

Similarly, for women, it might be the awareness of their own sexuality and its control that allows them to move away from those gender scripts and claim a preference for fewer children, since women who decide when to have sex have a smaller ideal of family size. As a sphere of life, sexuality can potentiate an individual's development and nourishment, but it can only do so if the person is in control of her own life. Otherwise, sexuality can be a sphere marked by power, violence, inadequacies and struggles, instead of fulfillment. If people are able to control when and how they engage in erotic behavior, then they would also be in control of their reproductive decisions. Therefore, those who believe it is their personal decision when to engage in sex exhibit a more internal locus of control that allows them to take hold of their own life. On the contrary, women who do not feel empowered to seek or refuse erotic behaviors and leave this decision to others 
In contrast, men exhibiting more masculinity and heteronormativity through homophobia shape a stronger preference for the number of children, probably enforcing their compliance with the masculinity standards. But high-status men prefer fewer children because their opportunity cost is higher than for low-status men. Likewise, people in rural areas also prefer more children than urban dwellers, suggesting that the cost of children are still cheaper in rural areas.

The results indicate that people end up making decisions that do not match their preferences and this particularly affects women: for both genders, older cohorts reported more children than preferred, but this phenomenon affected female cohorts at an age when their opportunity cost in the labor market might be highest, so that the economic cost of reproducing might be considerable for them. Women also end up with even more children than men, despite wanting fewer children. The gap between women and men is significant and reflects the fact that about half of single mothers in Costa Rica are abandoned by their partners (Budowski \& Rosero Bixby, 1999). Consequently, it is likely that this gap is due to men not acknowledging all their children. This gap also suggests that, when a couple negotiates its reproductive decisions, women are less successful than their partner in bargain for fewer children and having their preferred outcome. Therefore, such bargaining process might be marked by power structures within the household that leave women with more children than initially desired.

At the same time, a higher share of women also reported having multiple relationships compared to men. In contrast, a higher share of men reported never experiencing a relationship. It might be that women interpret their sexual experiences at a more personal level and sometimes picture themselves in relationships with partners who do not see themselves involved with them. If this were the case, it could explain partly why such a high percentage of women claim abandonment from their partners and why women are more vulnerable or willing to negotiate their reproductive decisions upwards. Alternatively, it could also be argued that women with a preference for children would seek different partners to better her chances of having successful offspring.

Women are also having sex at an earlier age and are at a higher risk than men of not receiving sexual education, which could make them more vulnerable to unwanted pregnancies. This, however, can be counteracted by non-religiosity and sex education. Education is also a powerful tool to allow women the opportunity to free themselves from motherhood, since more educated women are increasingly less likely to reproduce. This confirms results that are consistently observed throughout the world: female education is the best tool to control population growth by allowing women to take hold of their lives as individuals, not instruments of the species. But this might not be enough if women do not have room to negotiate their reproductive preferences, which is the case here: while women who feel entitled to initiate sex also view their lives with fewer children, they find themselves unable to negotiate in favor of their preferences within the household.

Regarding the correlates of the effective demand for children, the findings show that, on the one side, there seems to be a series of unconscious behaviors that push people into having more children to secure a stable number of surviving offspring (faced with the loss of a child) and reproduce through life (age and age squared) with a variety of potential partners (number of relationships), which can be linked to evolutionary explanations, such as the one offered by Lopreato and $\mathrm{Yu}$ (1988). And, on the other hand, education, sex education and work, which are social and economic in nature -and, therefore, associated with social explanations such as the quantity-quality model-, pull people towards the other direction, particularly women. Cultural variables associated with a more liberal thinking, such as not being religious, and human capital factors, such as education and sex education, are key in deciding not to reproduce, because they provide women with better tools to match their reproductive decisions to their taste. However, the positive sign of the coefficient associated with the knowledge of contraceptive methods might be indicative that access to contraception should be provided earlier. Future research could 
explore if this positive relation between fertility and contraceptive knowledge obeys to the fact that women really start learning about contraception after post-natal care.

As for the number of children effectively had, the data shows that non-Catholic Christians are more likely to have more children. This comes as no surprise, since such religious group tends to be more conservative due to the influence of the new Evangelical movements, which are more radical and right winged than traditional Christian groups, including Catholics. In contrast, nonChristian believers have fewer children than the reference group, but more than non-believers. It seems then that Christian institutions are more likely to reinforce the ideal of a larger family size. Likewise, initiating sexual activity early in life (before age 15) is associated with having more children. This is expected, since people who become sexually active at such an early age are usually victims of abuse and come from more conservative backgrounds. This result highlights the need to reach vulnerable populations from an early age in order to provide them with proper healthcare and contraception, as well as a safe environment. Living in a rural area is also associated with a larger descendance, probably also reflecting more conservative values and cheaper costs of childrearing.

Finally, it is worth noting that education is negatively and increasingly associated with the decision to reproduce, but this increasing trend is not observed when examining the number of children had, because more qualified individuals tend to have more children than semi-qualified ones. Consequently, the number of children is only decreasing with education for the female and pooled samples, but the male sample is U-shaped. This is probably explained by a wealth effect in male income: since literacy is almost universal in Costa Rica (97,6\%) and the country already met the two children threshold, the decreasing tendency of fertility relative to education might no longer be observable, because more qualified individuals can afford more high-quality children (Bagozzi \& Van Loo, 1978).

The most relevant finding of the study might be that both the preferences and number of children are associated with factors that can be linked to both evolutionary and socio-economic theories. And while there seems to be an innate behavior that anchors the preferred number of children to a reference point, the economic, educational, identity and gender equal policies that can provide a person with tools to forge her own life are able to move individuals slightly away from such reference point, creating a small margin of freedom for those people, but not much more than that.

\section{ACKNOWLEDGMENTS}

I am grateful to Arodys Robles, Valeria Lentini and Juan Robalino for their valuable feedback and suggestions.

\section{REFERENCES}

Ahmed, S., Li, Q., Liu, L., \& Tsui, A. O. (2012). Maternal deaths averted by contraceptive use: an analysis of 172 countries. The Lancet, 380(9837), 111-125. https://doi.org/10.1016/S0140-6736(12)60478-4

Alesina, A., Di Tella, R., \& MacCulloch, R. (2004). Inequality and happiness: are Europeans and Americans different? Journal of Public Economics, 88(9-10), 2009-2042. https://doi.org/10.1016/j.jpubeco.2003.07.006

Bagozzi, R. P., \& Van Loo, M. F. (1978). Fertility as Consumption: Theories from the Behavioral Sciences. Journal of Consumer Research, 4(4), 199-228. https://doi.org/10.1086/208700

Bailey, M. J. (2006). More Power to the Pill: The Impact of Contraceptive Freedom on Women's Life Cycle Labor Supply. The Quarterly Journal of Economics, 121(1), 289-320. https://doi.org/10.1093/qje/121.1.289 
De Beauvoir, S. (1999). El segundo sexo. Madrid: Cátedra.

Becker, G. S. (1960). An economic analysis of fertility. In Demographic and Economic Change in Developed Countries (pp. 209-240). Retrieved from https://www.nber.org/chapters/c2387

Becker, G. S. (1991). The demand for children. In A treatise on the family (pp. 135-154). Cambridge, Mass: Harvard University Press.

Becker, G. S. (1992). Fertility and the economy. Journal of Population Economics, 5(3), 185-201. https://doi.org/10.1007/BF00172092

Bousmah, M.-Q. (2017). The effect of child mortality on fertility behaviors is non-linear: new evidence from Senegal. Review of Economics of the Household, 15(1), 93-113. https://doi.org/10.1007/s11150-014-9264-7

Broussard, N. H., Chami, R., \& Hess, G. D. (2015). (Why) Do self-employed parents have more children? Review of Economics of the Household, 13(2), 297-321. https://doi.org/10.1007/s11150-013-9190-0

Bukowski, M., \& Rosero-Bixby, L. (1999). La Costa Rica sin padres: el reconocimiento de la paternidad y la pensión alimentaria. Retrieved September 1, 2017, from https://ccp.ucr.ac.cr/ seminario/manuscr.htm

Carey, A. D., \& Lopreato, J. (1995). The Evolutionary Demography of the Fertility-Mortality QuasiEquilibrium. Population and Development Review, 21(3), 613-630. https://doi.org/10.2307/2137752

Centro Centroamericano de Población. (2010). Encuesta Nacional de Salud Sexual y Reproductiva. Retrieved January 11, 2019, from http://encuestas.ccp.ucr.ac.cr/camerica/enssr2010.html

Centro Centroamericano de Población. (2015). II Encuesta Nacional de Salud Sexual y Reproductiva. Retrieved January 11, 2019, from

http://encuestas.ccp.ucr.ac.cr/camerica/enssr2010.html

Cicowiez, M., Saborío, G., \& Sánchez, M. V. (2016). Matriz de contabilidad social de Costa Rica 2012: Fundamentos metodológicos de su construcción. San José: Banco Central de Costa Rica.

Clark, A. E., \& Oswald, A. J. (2002). Well-being in panels. DELTA, Mimeo, 1.

De Tray, D. N. (1974). Child quality and the demand for children. In T. W. Schltz (Ed.), The economics of the family: marriage, children and human capital (pp. 91-119). Retrieved from https://www.nber.org/chapters/c2964

Di Tella, R. D., MacCulloch, R. J., \& Oswald, A. J. (2003). The Macroeconomics of Happiness. Review of Economics and Statistics, 85(4), 809-827. https://doi.org/10.1162/003465303772815745

Dolan, P., Peasgood, T., \& White, M. (2008). Do we really know what makes us happy? A review of the economic literature on the factors associated with subjective well-being. Journal of Economic Psychology, 29(1), 94-122. https://doi.org/10.1016/j.joep.2007.09.001

Frenette, M. (2011). Why do larger families reduce parental investments in child quality, but not child quality per se? Review of Economics of the Household, 9(4), 523-537. https://doi.org/10.1007/s11150-010-9115-0

Friedan, B. (2010). The feminine mystique. London: Penguin Classics.

Ganaba, R., Marshall, T., Sombié, I., Baggaley, R. F., Ouédraogo, T. W., \& Filippi, V. (2010). Women's sexual health and contraceptive needs after a severe obstetric complication ("near-miss"): a cohort study in Burkina Faso. Reproductive Health, 7(1). https://doi.org/10.1186/1742-4755-7-22

Glenn, N. D., \& McLanahan, S. (1981). The Effects of Offspring on the Psychological Well-Being of Older Adults. Journal of Marriage and Family, 43(2), 409-421. https://doi.org/10.2307/351391 
Goldin, C., \& Katz, L. F. (2002). The Power of the Pill: Oral Contraceptives and Women's Career and Marriage Decisions. Journal of Political Economy, 110(4), 730-770. https://doi.org/10.1086/340778

Goldstein, J., Lutz, W., \& Testa, M. R. (2003). The emergence of Sub-Replacement Family Size Ideals in Europe. Population Research and Policy Review, 22(5/6), 479-496. https://doi.org/10.1023/B:POPU.0000020962.80895.4a

Grossbard, S., \& Mukhopadhyay, S. (2013). Children, spousal love, and happiness: an economic analysis. Review of Economics of the Household, 11(3), 447-467. https://doi.org/10.1007/s11150-013-9200-2

Hazan, M., \& Zoabi, H. (2015, December 11). Highly educated women no longer have fewer kids. Retrieved December 13, 2015, from VoxEU.org website: https://voxeu.org/article/highly-educated-women-no-longer-have-fewer-kids

Instituto Nacional de Estadística y Censos [INEC]. (n.d.). Nacimientos. Primer semestre 2017. Características de la madre, del padre y de la persona recién nacida. Datos Preliminares. Retrieved September 1, 2017, from http://www.inec.go.cr/poblacion/nacimientos

Jiménez-Fontana, P. (2015). Analysis of non-remunerated production in Costa Rica. The Journal of the Economics of Ageing, 5, 45-53. https://doi.org/10.1016/j.jeoa.2014.09.004

Kalwij, A. S. (2000). The effects of female employment status on the presence and number of children. Journal of Population Economics, 13(2), 221-239. https://doi.org/10.1007/s001480050135

Kasy, M., \& Ramos-Chaves, A. (2014). The Impact of Changing Family Structures on the Income Distribution among Costa Rican Women 1993-2009. Feminist Economics, 20(2), 122-144. https://doi.org/10.1080/13545701.2013.862343

Kennedy, E., Gray, N., Azzopardi, P., \& Creati, M. (2011). Adolescent fertility and family planning in East Asia and the Pacific: a review of DHS reports. Reproductive Health, 8(1). https://doi.org/10.1186/1742-4755-8-11

Klepinger, D., Lundberg, S., \& Plotnick, R. (1999). How Does Adolescent Fertility Affect the Human Capital and Wages of Young Women? The Journal of Human Resources, 34(3), 421-448. https://doi.org/10.2307/146375

Kohler, H.-P., Behrman, J. R., \& Skytthe, A. (2005). Partner + Children = Happiness? The Effects of Partnerships and Fertility on Well-Being. Population and Development Review, 31(3), 407445. https://doi.org/10.1111/j.1728-4457.2005.00078.x

Llovet, J. J. (1989). Relación entre fecundidad e ingresos: revisión de algunas interpretaciones. Estudios Demográficos y Urbanos, 4(1), 139-159. https://doi.org/10.24201/edu.v4i1.706

Lopreato, J., \& Yu, M. (1988). Human fertility and fitness optimization. Ethology and Sociobiology, 9(5), 269-289. https://doi.org/10.1016/0162-3095(88)90009-X

Lundholm, M., \& Ohlsson, H. (2002). Who takes care of the children? The quantity-quality model revisited. Journal of Population Economics, 15(3), 455-461. https://doi.org/10.1007/s001480100071

Malarcher, S., Meirik, O., Lebetkin, E., Shah, I., Spieler, J., \& Stanback, J. (2011). Provision of DMPA by community health workers: what the evidence shows. Contraception, 83(6), 495-503. https://doi.org/10.1016/j.contraception.2010.08.013

Margolis, R., \& Myrskylä, M. (2011). A Global Perspective on Happiness and Fertility. Population and Development Review, 37(1), 29-56. https://doi.org/10.1111/j.1728-4457.2011.00389.x 
McDonald, P. (2002). Sustaining Fertility through Public Policy: The Range of Options. Population, 57(3), 417-446. https://doi.org/10.3917/popu.203.0423

McQuillan, K. (2004). When Does Religion Influence Fertility? Population and Development Review, 30(1), 25-56. https://doi.org/10.1111/j.1728-4457.2004.00002.x

Mekonnen, W., \& Worku, A. (2011). Determinants of low family planning use and high unmet need in Butajira District, South Central Ethiopia. Reproductive Health, 8(1). https://doi.org/10.1186/1742-4755-8-37

Mincer, J. (1974). Schooling, experience, and earnings. Retrieved from https://www.nber.org/books/minc74-1

Mörk, E., Sjögren, A., \& Svaleryd, H. (2013). Childcare costs and the demand for children-evidence from a nationwide reform. Journal of Population Economics, 26(1), 33-65. https://doi.org/10.1007/s00148-011-0399-Z

Myrskylä, M., \& Margolis, R. (2014). Happiness - before and after the Kids (No. 642). DIW Berlin, The German Socio-Economic Panel (SOEP).

Neels, K., Murphy, M., Ní Bhrolcháin, M., \& Beaujouan, É. (2017). Rising Educational Participation and the Trend to Later Childbearing: Rising Educational Participation and Later Childbearing. Population and Development Review, 43(4), 667-693. https://doi.org/10.1111/padr.12112

Potter, J. E. (1988). Birth Spacing and Child Survival: A Cautionary Note Regarding the Evidence from the WFS. Population Studies, 42(3), 443-450. https://doi.org/10.1080/0032472031000143576

Prata, N. (2009). Making family planning accessible in resource-poor settings. Philosophical Transactions of the Royal Society B: Biological Sciences, 364(1532), 3093-3099. https://doi.org/10.1098/rstb.2009.0172

Preston, S. H. (1978). Introduction. In S. H. Preston (Ed.), The Effects of infant and child mortality on fertility (pp. 1-18). New York: Academic Press.

Quirós Rojas, I. (2012). Algunas consideraciones sobre los derechos sexuales y reproductivos. In Ministerio de Salud (Ed.), Visualizando la salud reproductiva y la sexualidad desde diversas perspectivas: un análisis a partir de la Encuesta de Salud Sexual y Reproductiva (pp. 137146). San José: Ministerio de Salud.

Robles, A., \& González, A. (2012a). La fecundidad en Costa Rica: 1992-2010. In Ministerio de Salud (Ed.), Visualizando la salud reproductiva y la sexualidad desde diversas perspectivas: un análisis a partir de la Encuesta de Salud Sexual y Reproductiva (pp. 15-30). San José: Ministerio de Salud.

Robles, A., \& González, A. (2012b). Planificación familiar. In Ministerio de Salud (Ed.), Visualizando la salud reproductiva y la sexualidad desde diversas perspectivas: un análisis a partir de la Encuesta de Salud Sexual y Reproductiva (pp. 31-48). San José: Ministerio de Salud.

Rosero-Bixby, L. (1998). Child mortality and the fertility transition: aggregated and multilevel evidence from Costa Rica. In M. Montgomery (Ed.), From Death to Birth: Mortality Decline and Reproductive Change (pp. 384-410). https://doi.org/10.17226/5842

Rosero-Bixby, L., \& Oberle, M. W. (1989). Fertility change in Costa Rica 1960-84: analysis of retrospective lifetime reproductive histories. Journal Biosocial Science, 21(4), 419-432. https://doi.org/10.1017/S0021932000018150

Rosero Bixby, L., \& Casterline, J. B. (1995). Difusión por interacción y transición de la fecundidad: evidencia cuantitativa y cualitativa de Costa Rica. 29-78. 
Schultz, T. P. (1997). Chapter 8 Demand for children in low income countries. In Handbook of Population and Family Economics (Vol. 1, pp. 349-430). https://doi.org/10.1016/S1574-003X(97)80025-6

Schultz, T. W. (Ed.). (1974). Economics of the family: marriage, children, and human capital. Retrieved from https://www.nber.org/books/schu74-1

The DHS Program. (2018). The DHS Program - DHS Questionnaires. Retrieved January 31, 2019, from https://dhsprogram.com/what-we-do/survey-types/dhs-questionnaires.cfm

Turchi, B. A. (1975). Microeconomic Theories of Fertility: A Critique. Social Forces, 54(1), 107-125. https://doi.org/10.2307/2576080

Twenge, J. M., Campbell, W. K., \& Foster, C. A. (2003). Parenthood and Marital Satisfaction: A MetaAnalytic Review. Journal of Marriage and Family, 65(3), 574-583. https://doi.org/10.1111/j.1741-3737.2003.00574.x

van Praag, B. M. S., Frijters, P., \& Ferrer-i-Carbonell, A. (2003). The anatomy of subjective wellbeing. Journal of Economic Behavior \& Organization, 51(1), 29-49. https://doi.org/10.1016/S0167-2681(02)00140-3

Yeakey, M. P., Muntifering, C. J., Ramachandran, D. V., Myint, Y., Creanga, A. A., \& Tsui, A. O. (2009). How Contraceptive Use Affects Birth Intervals: Results of a Literature Review. Studies in Family Planning, 40(3), 205-214. https://doi.org/10.1111/j.1728-4465.2009.00203.x 